\title{
Glyphosate Pollution Treatment and Microbial Degradation Alternatives, a Review
}

\author{
María Luisa Castrejón-Godínez ${ }^{1}$, Efraín Tovar-Sánchez ${ }^{2}{ }^{\infty}$, Leticia Valencia-Cuevas ${ }^{2}$, \\ Marcos Eduardo Rosas-Ramírez ${ }^{3}$, Alexis Rodríguez ${ }^{3, *(1)}$ and Patricia Mussali-Galante ${ }^{3, *}$ \\ 1 Facultad de Ciencias Biológicas, Universidad Autónoma del Estado de Morelos, Cuernavaca 62209, Mexico; \\ mlcastrejon@uaem.mx \\ 2 Centro de Investigación en Biodiversidad y Conservación, Universidad Autónoma del Estado de Morelos, \\ Cuernavaca 62210, Mexico; efrain_tovar@uaem.mx (E.T.-S.); leticia.valencia@uaem.mx (L.V.-C.) \\ 3 Centro de Investigación en Biotecnología, Universidad Autónoma del Estado de Morelos, Cuernavaca 62210, \\ Mexico; marcos.rosas@uaem.edu.mx \\ * Correspondence: alexis.rodriguez@uaem.mx (A.R.); patricia.mussali@uaem.mx (P.M.-G.); \\ Tel. +52-(777)-5223970 (A.R.); +52-(777)-2577891 (P.M.-G.)
}

check for updates

Citation: Castrejón-Godínez, M.L.; Tovar-Sánchez, E.; Valencia-Cuevas, L.; Rosas-Ramírez, M.E.; Rodríguez, A.; Mussali-Galante, P. Glyphosate Pollution Treatment and Microbial Degradation Alternatives, a Review. Microorganisms 2021, 9, 2322. https://doi.org/10.3390/ microorganisms 9112322

Academic Editor: Hermann J. Heipieper

Received: 2 October 2021

Accepted: 8 November 2021

Published: 10 November 2021

Publisher's Note: MDPI stays neutral with regard to jurisdictional claims in published maps and institutional affiliations.

Copyright: (c) 2021 by the authors. Licensee MDPI, Basel, Switzerland. This article is an open access article distributed under the terms and conditions of the Creative Commons Attribution (CC BY) license (https:/ / creativecommons.org/licenses/by/ $4.0 /)$.
Abstract: Glyphosate is a broad-spectrum herbicide extensively used worldwide to eliminate weeds in agricultural areas. Since its market introduction in the 70's, the levels of glyphosate agricultural use have increased, mainly due to the introduction of glyphosate-resistant transgenic crops in the 90's. Glyphosate presence in the environment causes pollution, and recent findings have proposed that glyphosate exposure causes adverse effects in different organisms, including humans. In 2015, glyphosate was classified as a probable carcinogen chemical, and several other human health effects have been documented since. Environmental pollution and human health threats derived from glyphosate intensive use require the development of alternatives for its elimination and proper treatment. Bioremediation has been proposed as a suitable alternative for the treatment of glyphosaterelated pollution, and several microorganisms have great potential for the biodegradation of this herbicide. The present review highlights the environmental and human health impacts related to glyphosate pollution, the proposed alternatives for its elimination through physicochemical and biological approaches, and recent studies related to glyphosate biodegradation by bacteria and fungi are also reviewed. Microbial remediation strategies have great potential for glyphosate elimination, however, additional studies are needed to characterize the mechanisms employed by the microorganisms to counteract the adverse effects generated by the glyphosate exposure.

Keywords: glyphosate; environmental pollution; microorganisms; pesticide; remediation

\section{Introduction}

Glyphosate (N-Phosphonomethyl-glycine) is a broad-spectrum herbicide extensively used worldwide to eliminate weeds in agricultural areas, control vegetation in urban areas, and accelerate the harvest of several crops [1]. This phytotoxic activity of glyphosate was discovered at the beginning of the 70's and it has been employed in different herbicide formulations since [2-4]. Glyphosate was patented as a pesticide with disrupting activity and lethal effects on a broad spectrum of plants with active photosynthesis $[5,6]$. Glyphosate herbicide activity has been attributed to its blocking effects on the shikimic acid pathway, through the inactivation of the key enzyme 5-enolpyruvylshikimate-3-phosphate synthase (EPSPS), due to its profile as a phosphoenolpyruvate analog (Figure 1). The blocking of the EPSPS enzyme prevents aromatic amino acids (phenylalanine, tyrosine, and tryptophan) biosynthesis and subsequent protein production [7], killing plants in a time of 1-3 weeks [8,9]. Glyphosate was proposed as a plant selective pesticide due to the absence of the shikimic acid pathway in animals and humans.

Since the glyphosate introduction to the market, it has been perceived as a less toxic weed control alternative, safe for agricultural workers and non-target organisms. In 
addition, glyphosate shows high effectiveness for eradicating weeds from crop fields before planting begins and for vegetation control on non-cultured areas, as the edge of roads and the sides of railways [10]. This perception of safety led to the growing popularity in the use of glyphosate-based herbicides among farmers worldwide [5], to the existence in the market of more than 750 products [11], and to be considered the most effective herbicide in all of history [12].

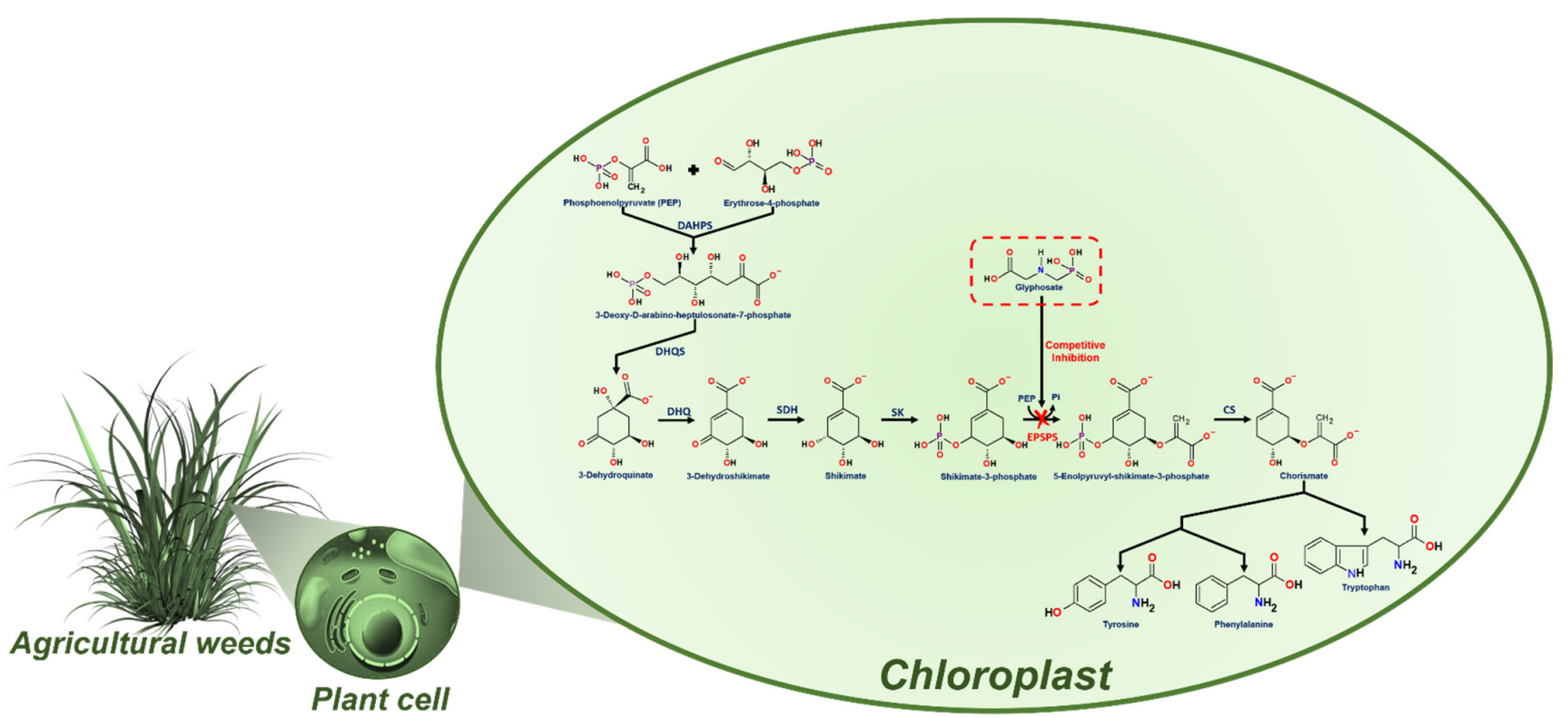

Figure 1. Glyphosate action mechanism through the inhibition of the shikimate pathway. Enzymes implicated in the pathway, DAHPS: 3-Deoxy-D-arabino-heptulosonate-7-phosphate synthase; DHQS: 3-Dehydroquinate synthase; DHQ: 3-Dehydroshikimate dehydratase; SDH: shikimate-5-dehydrogenase; SK: shikimate kinase; EPSPS: 5-Enolpyruvyl shikimate 3-phosphate synthase; and CS: chorismate synthase.

The worldwide use of glyphosate has become an environmental problem. The volume of application of this herbicide has been increasingly high in response to the appearance of resistant weeds, the introduction of transgenic glyphosate-resistant crops, and the adoption of new patterns in its agricultural uses, as its application as a desiccant to accelerate the harvest of grains and other crops [10,13]. Due to the intensive glyphosate use, the environmental presence and adverse effects of this herbicide are each time more evident. In addition, the toxic effects of the glyphosate-based commercial formulas are more significant due to the addition of adjuvants (surfactants), which have their own toxicity, but which also enhance the toxicity of glyphosate [8,14], highlighting the use of mixtures of polyethoxylated amines (POEA) [15]. Some POEA show toxicities 10-60 times higher than glyphosate in aquatic organisms and 4-50 times higher in mammals [16,17].

Glyphosate is known as a chelating agent that binds macro- and micronutrients, essential for several plant processes and the resistance to pathogens, sequestering of such nutrient can compromise plant resistance development, but also affect animals and human health [18]. The global increase in the intensive use of glyphosate-based herbicides causes the release and presence of residues of this chemical in the soil, water, and air, compromising the integrity of the surrounding environments and constituting a threat for the organisms that inhabit these polluted areas [19]. In this sense, different studies have evidenced the presence of glyphosate residues in surface soil, and their transport to the deep soil layers or to bodies of water near agricultural fields [20-22].

It has been documented that glyphosate is a highly water-soluble molecule. Hence, glyphosate can be dispersed through runoff processes to different superficial water bodies as rivers and lagoons or be absorbed by the soil particles [23] causing pollution and favoring its availability for the organisms that feed through sediment filtration [24]. For 
example, glyphosate is highly toxic for aquatic organisms such as algae, ferns, and fishes, while moderately toxic to amphibians, crustaceans, and earthworms [25]. Furthermore, in recent studies, glyphosate residues have been identified in several agricultural products consumed by human populations [2,26]. Moreover, residues of this agrochemical were detected in food, human blood and urine, and water supplies. In a contrasting way, the initial reports considered glyphosate as a safe molecule with low toxicity on non-target organisms [2]. However, recently, the International Agency for Research on Cancer (IARC) classified glyphosate as a probable carcinogen [11], which can negatively affect mammalian biology through multiple ways, like those related to genotoxic effects and its ability to trigger oxidative stress [2].

The environmental and toxicological adverse impacts of glyphosate have been broadly reviewed. Several studies related to the identification of glyphosate in the environment and farm products destined for animal and human consumption have been published. Moreover, different toxicological studies have evaluated the toxicity of glyphosate on different organisms and the adverse effects of both occupational and non-occupational exposure to this herbicide in humans. However, reviews covering the treatment alternatives and the potential of microorganisms for glyphosate biodegradation are still limited. Since glyphosate-based herbicides are the most widely used globally, they promote severe effects on the environment and human health. This review aims to describe its environmental impacts, the risk for environmental and human health, the analytical methodologies developed for the detection and analysis of contamination by this type of agrochemicals, analyze resent research in microbial glyphosate degradation, and delves into the biodegradation mechanisms employed by microorganisms. Finally, we propose strategies for its control and prevention as well as some alternatives for bioremediation of polluted environments by glyphosate.

\section{Environmental Impacts of Glyphosate}

For 40 years, glyphosate has been widely used as an active chemical component of more than 750 commercial herbicides under the assumption that its side effects were minimal $[11,27]$. However, this compound's intensive and large-scale use in industrialized and developing countries motivated the scientific community to evaluate the risks associated with the possible accumulation of its residues in various environmental systems and its effects on environmental and human health [28]. In this sense, recent evidence shows that herbicides containing glyphosate can contaminate the soils around the treated areas, glyphosate is adsorbed to clays and organic matter, slowing down its degradation by the action of microorganisms, leading to an accumulation in soils over time [29-31], the persistence of glyphosate in high clay content soil reaches more than a year [31,32].

Glyphosate has a great capacity for adsorption in the clay and organic matter present in soils, being considered as a low mobility compound, so that it is assumed that it does not represent a significant risk for the contamination of the water sources [33-35]. However, the scientific literature has reported the presence of this compound dissolved in groundwater [36,37], the transport of soil particles with glyphosate in surface water [21,37,38], as well as its adsorption in the sediments of water bodies [35]. Moreover, the glyphosate deposited in the first centimeters of the superficial soil layer is susceptible to wind erosion and atmospheric transport [39,40], consequently, glyphosate has been detected in the air, rain, and water from melting snow [21,41]. Finally, glyphosate has also been reported in seawater, where it is very persistent [42] and in drinking water [43].

Resulting from its accumulation and persistence in the soil, glyphosate can affect exposed organisms in this environmental compartment [44]. For example, it has been reported that glyphosate can affect the activity of soil microorganisms that are involved in biogeochemical cycles, the mineralization of organic remains, the immobilization and solubilization of minerals, and the degradation of other xenobiotics [45-47]. Likewise, a reduction in the reproduction rate, biomass, and DNA damage in earthworms has been reported [48-50], as well as adverse effects in other small size organisms, such as ne- 
matodes, distributed in soils [51]. Moreover, in plant species, the direct effects of their exposure to glyphosate are related to the inhibition of the activity of antioxidant enzymes and the induction of reactive oxygen species (ROS), which promote cell damage and physiological alterations in processes such as photosynthesis and the production of secondary metabolites [52]. Furthermore, traces of this compound can be detected in plant tissues of temperate zone species up to more than 12 years after the treatment [4]. Glyphosate indirectly changes the rhizosphere microbiome, which affects plant health $[28,53]$.

In water bodies, the negative impacts of glyphosate have been observed in organisms such as protozoa, mussels, crustaceans, frogs, and fish [28]. Similar to that reported in terrestrial ecosystems, the presence of glyphosate in fish produces metabolism alterations, leading to the overproduction of reactive oxygen species and oxidative stress resulting in kidney damage [54]. Likewise, other studies have linked glyphosate exposure to DNA damage and chromosomal alterations in fish $[55,56]$. The presence of glyphosate not only has effects at the level of individual organisms, but alterations in the interactions between species have also been documented. As an example, an increase in the levels of susceptibility of fish to its parasites has been documented $[57,58]$. Similarly, unwanted effects of glyphosate exposure have been reported in bee species that provide valuable ecosystem services such as pollination [59]. Finally, glyphosate has been detected in animal feed, animal meat, and urine, as well as in the food intended for human consumption, which is why the presence of this herbicide has been detected in samples of breast milk and urine [5]. Another additional environmental risk associated with the presence of glyphosate, which has not been adequately considered, is that it is a potent mineral chelator [18] whose application can lead to the reduction of macro and micronutrients that are essential cofactors in many biological processes of glyphosate-treated plants and potentially also for the organisms that feed on them. Consequently, a reduced supply of nutrients in the treated plants can compromise their resistance to diseases. In the case of humans and other animals that consume food obtained from plants treated with glyphosate, the residues of this herbicide and the reduced levels of nutrients can also have an impact on their health $[18,60]$. Therefore, to minimize its environmental and human health impacts, monitoring and detection of its presence in different environments, as well as the evaluation of exposure to this herbicide in humans, is of utmost importance.

\section{Glyphosate Human Health Threats}

Humans have been exposed to glyphosate directly through occupational exposure or indirectly through various sources [61]. Occupational exposure includes agricultural workers, farmers, gardeners, and people who work in plants that process glyphosate [62]. These people can be exposed to glyphosate through inhalation, dermal and ocular contact. In contrast, the indirect exposure includes the consumption of water or food contaminated with glyphosate residues [63] or the environmental exposure to residues or products of its transformation, such as aminomethyl phosphonic acid (AMPA) in environmental matrixes such as air, water, or soil $[61,62]$.

The mode of action of glyphosate consists of the inhibition of the enzyme EPSPS involved in the biosynthesis of the aromatic amino acids tyrosine, tryptophan, and phenylalanine through the shikimate pathway in plants [64]. Therefore, glyphosate was proposed as a low toxicity compound for non-target organisms and was considered relatively safe for humans, according to the results of different exposure studies carried out in rodents, chickens, and amphibians [12,13,65,66].

More recently, it was determined that the toxicity of commercial herbicides based on glyphosate is exacerbated by the presence of surfactant compounds in the formulation, being polyoxyethyleneamine (POEA) the most common $[5,61]$. This compound uncouples elements of phosphorylation oxidative stress, causing oxidative stress and cardiotoxicity [67]. Thus, in 2015, the World Health Organization reclassified glyphosate as a possible human carcinogen $[11,68,69]$. Glyphosate reclassification into the group 2A of the International Agency for Research on Cancer (IARC) was based on the review of the accumulated 
evidence provided by experts in cancer and toxicology, which has contributed to a better understanding of the toxicity of the compound for all kinds of exposed organisms in natural areas, and in experimental animals, and its mechanisms of action [70].

Among the most relevant information on the effects caused by glyphosate exposure in humans are the studies by Samsel and Seneff (2013b) [71], which indicated that exposure to the herbicide represented the main factor causing gluten intolerance and gastrointestinal disorders, as well as interference in the assimilation of micronutrients such as iron, cobalt, molybdenum, copper, and amino acids such as tryptophan, tyrosine, methionine, and selenomethionine. Subsequently, Samsel and Seneff (2013a) [60] and Schinasi and Leon (2014) [72] evidenced an association between non-Hodgkin's lymphoma and agrochemical exposure. In particular, the latest work showed that occupational exposure to glyphosate increases the relative risk of developing this disease and the development of B-cell lymphoma. Other reports of chronic exposure to the herbicide in human populations show the association with conditions such as allergies, and asthma [73], cardiovascular diseases [74], autism, and chronic degenerative diseases such as multiple myeloma [75]. Cytotoxic damage has also been reported in chorioplacental cells of humans, which triggers inhibition in the synthesis of progesterone as a secondary effect [76]. Recent reviews suggest that glyphosate and glyphosate-based herbicides promote cytotoxic and genotoxic effects, a significant increase in oxidative stress, disruption of the estrogen pathway, adverse effects on various cognitive processes, and an association with the development of certain cancers $[77,78]$. The studies mentioned above compile evidence of the high glyphosate toxicity and establish this compound as a menace to the health of the agricultural population that has a history of direct exposure and for whom the exposure has been indirect through the consumption of food or water with residues of glyphosate. Human individuals exposed to this compound have presented multiple organ toxicity, nephrotoxicity, hepatotoxicity, gastrointestinal, cardiovascular, and respiratory effects [62,79].

\section{Environmental Risk Assessment through Glyphosate and Its Metabolites Detection}

Several methodologies have been developed to detect the presence and amount of glyphosate in different environmental samples, including soils, sediments, plant material, surface water, and human fluids [80,81]. However, the chemical characteristics of glyphosate, such as its high solubility in water, insolubility in organic solvents, nonvolatility, high sorption to the soil, as well as the lack of fluorophores and chromophores groups in its molecular structure make its detection and quantification in environmental samples difficult $[81,82]$. To improve the analytical detection of glyphosate and AMPA, the primary toxic metabolite derived from glyphosate degradation, it is necessary to carry out a first derivation step before the analytical determination [83]. The derivatizing agents used for the detection of glyphosate modify its properties and make it detectable by various spectroscopic techniques. A recent review revealed that derivatization is commonly done by acylating agents, alkylchloro or fluoro formates, benzenesulfonyl, and phthalaldehyde [34]. For the glyphosate and AMPA detection through HPLC analyses several aromatic reagents have been employed as derivatizing groups such as 2,5-dimethyl benzene sulfonyl chloride, $p$-toluenesulphonyl chloride, $o$-nitrobenzene-sulfonyl chloride, $o$-phthalaldehyde (OPA), 9-fuorenylmethylchoroformate (FMOC) [84-87]. In the same analytical technique, the derivatization of glyphosate and AMPA with OPA, after the chromatographic column separation, allows their detection and analysis through a fluorescence detector (FLD).

Alkyl chloroformates like isobutyl chloroformate and isopropyl chloroformate replace the active hydrogen atoms present in the glyphosate molecule with an aliphatic or aromatic group and convert them into their ester derivatives. These ester derivatives are less polar and more stable than glyphosate. These transformations improve the chromatographic properties of glyphosate, and hence its detection by gas chromatography becomes easier. There is another derivatizing reagent called FMOC, which transforms glyphosate into a carbamate derivative. These carbamate derivatives are more stable and show good chromatographic properties. The fourth type of derivatizing reagent is 4-methoxybenzene- 
sulfonyl fluoride which converts glyphosate into sulphonamide derivative, whereas OPA changes it into phosphoramide derivative. These sulfur and phosphorus derivatives bring fluorescent properties to glyphosate and make detection easy by 'flame photometric detector' through liquid chromatography. Another commonly used reagent, ninhydrin, converts glyphosate's amino group into a highly fluorescent compound that can be detected easily by ultraviolet spectroscopy. The reagents like 4-chloro-7-nitrobenzofurazan, naphthalene2,3carboxaldehyde, and fluorescein isothiocyanate also introduce fluorescence into glyphosate molecules [34].

Methods that have been used for glyphosate and AMPA extraction, derivation, preconcentration, and quantification in environmental samples [88], include UV capillary zone electrophoresis (CZE) coupled to conductivity detection (CD) and UV detection [89], condensation nucleation light scattering detection (CNLSD) [90]; high performance liquid chromatography (HPLC) coupled to mass spectrometry (MS) [91]; ion chromatography (IC) with CD and inductively coupled plasma MS (ICPMS), capillary electrophoresis (CE) with capacity couple contactless conductivity detection (C4D) [91]; fluorescence ICPMS [92]; electrochemical detection [93]; HPLC coupled with Tandem MS [94]; a flow injection (FI) system with electrochemiluminescence (ECL) detection [95], enzyme-linked immunosorbent assay (ELISA) [96-99]; gas chromatography (GC) coupled to MS [97], time-of-flight MS (TOF-MS) [100].

In general, most of these technologies require high-end equipment and resources, making glyphosate detection and quantification expensive and slow [101]. Undoubtedly, having efficient methodologies and techniques to detect the presence and quantity of glyphosate, its metabolites, or adjuvants are necessary to improve the knowledge of the potential risks to humans and environmental health from exposure to this herbicide, so this will be a field of great relevance in the coming years.

\section{Need for Pollution Prevention and Treatment}

The concentration of glyphosate in the herbicidal commercial formulations may vary between 0.94 and $94 w / w \%, 36 \%$ being the most common proportion [102]. The selection of the commercial glyphosate formulation and the dosage applied to the crop fields are established according to the needs of farm producers. However, the recommended application dose of commercial formulation (36\% pure glyphosate) is around 1.5-6 L (0.54-2.2 kg) by hectare (ha). In the European Union, glyphosate use in annual crops systems such as corn and wheat ranges from 0.5 to $2.7 \mathrm{~kg} / \mathrm{ha}$, while in perennial crops such as olive groves and vineyards, glyphosate dose ranges from 0.2 to $2.5 \mathrm{~kg} / \mathrm{ha}$ [103].

After application, glyphosate is quickly attached to the soil, where it and AMPA may persist from a few days up to a year, while in water, due to its high solubility, glyphosate enters water bodies and its half-life can reach three months [104]. In a study carried out in soil of different countries of the European Union, glyphosate and AMPA residues were identified in concentrations from $0.5 \mathrm{mg} / \mathrm{kg}$ up to values higher than $1000 \mathrm{mg} / \mathrm{kg}$, the AMPA concentrations were higher with respect to glyphosate in all sampled soils [40]. In several countries of Europe, North and South America, the reported glyphosate concentration ranges from 0.1 to $328 \mu \mathrm{g} / \mathrm{L}$ in surface water samples, while from 0.7 to $2.5 \mu \mathrm{g} / \mathrm{L}$ in groundwater samples [28].

Glyphosate shows different range toxicities according to the evaluated organisms, in acute toxicity studies glyphosate may cause mortality in aquatic organisms such as Daphnia magna $\left(\mathrm{EC}_{50} 40 \mathrm{mg} / \mathrm{L}\right)$, Lepomis macrochirus $\left(\mathrm{EC}_{50} 47 \mathrm{mg} / \mathrm{L}\right)$ and rainbow trout Oncorhynchus mykiss $\left(\mathrm{EC}_{50} 38 \mathrm{mg} / \mathrm{L}\right)$, while in human cells, cytotoxicity has been observed in concentrations higher than $10,000 \mathrm{mg} / \mathrm{L}$. With respect to oral exposure, glyphosate toxicity has been observed in rats (90 days exposure) at concentrations of $300 \mathrm{mg} / \mathrm{kg} /$ day, while in dogs (90 days exposure) toxic effects were observed at $1000 \mathrm{mg} / \mathrm{kg} /$ day [17].

The toxicity of glyphosate has been evaluated in rodents, through oral exposure (technical glyphosate; $>80-90 \%$ purity), we have observed that the studies using commercial formulations using animals, are limited. In animals, the toxic effects of glyphosate oral 
exposure vary according to the dosage, at $175 \mathrm{mg} / \mathrm{kg} /$ day in acute exposure ( $\leq 14$ days) diarrhea is observed, concentrations ranging from $300-460 \mathrm{mg} / \mathrm{kg} /$ day may cause diarrhea, salivary glands cytoplasm changes, and inclusively death in intermediate exposure (15-364 days) and gastric mucosa inflammation and salivary glands cytoplasm changes in chronic exposure (>365 days); these adverse effects may be extrapolated to humans [102].

Although glyphosate as an active chemical component of herbicides may have low toxicity to exposed organisms, the effects of chronic exposure are not known [61]. Another important risk is that it has been shown that the presence of its metabolites (AMPA) and its adjuvants as POEA in commercial formulations may have higher levels of toxicity than glyphosate alone [101]. In addition, the persistence of glyphosate, adjuvants, and metabolites in the environment may be greater than previously considered, which, together with the difficulties in their detection [105], implies a greater risk for exposed organisms. In this sense, it has already been documented that glyphosate has caused toxic effects in non-target organisms found in soil and water, including various plants, animals, and bacteria $[34,106]$. Another serious concern is that glyphosate may compromise biodiversity as it has reduced the availability of weeds that serve as an important food source for many species [34]. This information makes it evident that our knowledge of glyphosate's ecological safety, its behavior in natural environments, how it interacts with wild organisms, and its degradation routes are insufficient. In addition to those mentioned above, the association of glyphosate with carcinogenesis in humans and other chronic diseases reveals the urgent need to prevent contamination in natural environments (soil and water bodies) and the search for alternatives for its removal, control, and treatment in the environment.

\section{Physicochemical Treatments for Glyphosate Remediation}

Physicochemical processes such as adsorption, membrane filtration, and coagulation have proven to be efficient and economical for removing glyphosate $[107,108]$. Adsorption is a widely used process for treating and purifying water contaminated with glyphosate due to its simplicity, non-toxicity, low-cost design, and high efficiency. The adequate selection of adsorbent material is crucial, among the materials that have been used as adsorbents to remove glyphosate from wastewater are clay substances [109], activated carbon [110,111], zeolite [112]; biochar [113,114], graphene oxide and iron-based adsorbing materials [115], resins $[116,117]$. The glyphosate adsorption process occurs through physical and chemical interactions between the functional groups of the glyphosate molecule $\left(-\mathrm{COOH},-\mathrm{NH}_{2}\right.$, and $\left.-\mathrm{PO}(\mathrm{OH})_{2}\right)$ and the surface of the adsorbent [107]. In general, it has been found that under acidic conditions, the adsorption of glyphosate by different adsorbents is more favorable, so it has been proposed that $\mathrm{pH}$ is one of the most determining factors affecting the glyphosate adsorption process [108,113]. Likewise, the concentration of the pollutant, the temperature, the adsorbent dose, and the ionic strength are also key factors for the overall efficiency of this process [115]. Although adsorption is an efficient method for the treatment of glyphosate in low concentrations, some drawbacks limit its application in practice: (1) successful glyphosate adsorption requires acidic conditions, it is not recommended to drastically change the $\mathrm{pH}$ of the wastewater that later could be released into the environment, so that the treated water needs a neutralization step prior to the its environment release; (2) there is no selectivity of adsorbents for glyphosate, which is a disadvantage considering that wastewater contains many other pollutants; (3) most of the studies have been at the laboratory level using ex-professo prepared glyphosate aqueous solutions; and (4) the removal of the residue after adsorption continues to be a problem that also needs to be considered $[107,108]$. Using this technology as the principal treatment is not recommended (although the affinity of glyphosate with some of the adsorbents is quite good), so it has been suggested to use it as a possible secondary treatment when the concentration of other pollutants is low.

Another technology that has been used to treat glyphosate is membrane filtration [118-120]. This system works as a barrier for matter transport of an influent stream and separates it into two effluent streams: the permeate and the retentate or con- 
centrate [118]. An advantage of the membrane filtration process is that it does not break down the glyphosate into molecules so that it does not produce harmful by-products that could be more toxic than the original contaminant. In addition, the contaminant could be recovered after the membranes are saturated. However, a disadvantage of membrane filtration could be its specificity to reject specific pollutants since, in real conditions, the characteristics and composition of the water could change, compromising the efficiency of the filtration process [107]. Additionally, in several studies, glyphosate removal has not been done in real polluted water. Therefore, for successful membrane filtration, it is necessary to evaluate in more detail the effect of natural organic matter on the efficiency of this system for water contaminated with commercial glyphosate formulations.

Advanced oxidation processes include numerous techniques based on the formation of strong oxidants agents, such as hydroxyl radicals $\left(\mathrm{OH}^{-}\right)$, which can help to degrade organic pollutants, conducting to its complete mineralization in $\mathrm{CO}_{2}, \mathrm{H}_{2} \mathrm{O}$, and inorganic salts [121,122]. Among them, we can mention Fenton reagent, photo-Fenton, ozonation, photocatalysis, $\mathrm{H}_{2} \mathrm{O}_{2}-\mathrm{UV}$, and electrochemical treatments [108,122]. For example, Fenton oxidation has been a successful technology for glyphosate treatment with the advantages of simple operation, no mass transfer limitation, and easy implementation as a standalone or hybrid system [123]. Through this process, the degradation of toxic organic molecules is achieved by employing strong chemical oxidizing species.

However, the continuous loss of oxidants and iron ions, the formation of solid sludge, and the high costs and risks related to the handling, transport, and storage of reagents are some drawbacks in the Fenton process [124]. To avoid the disadvantages that are associated with the Fenton process, combined processes have been proposed, such as the use of electro-Fenton and photo-Fenton treatments. Application of this alternative Fenton process seek to enhance the production of $\mathrm{OH}$ - radicals through electrochemical reactions or irradiation with ultraviolet or visible light, respectively [125]. Complete elimination of glyphosate and good mineralization have been reported through the use of electro-Fenton and photo-Fenton treatments [126].

However, another disadvantage is that this technology has not been tested in real systems [108]. Electrochemical oxidation is one of the cleanest technologies to degrade glyphosate compared to other advanced oxidation processes [107]. It offers high efficiency without adding chemical products $[127,128]$. This technology is based on anodic oxidation reactions to degrade organic matter to its complete mineralization or even less complex molecules that are biodegradable [129]. For this degradation process, pH, initial glyphosate concentration, electronic composition, electrolysis, and current density are important parameters $[130,131]$. The use of electrochemical oxidation has been efficient for the degradation of glyphosate since it reaches almost the total mineralization of this pollutant $[127,131,132]$. However, the main disadvantages of the process are associated with the high cost of the electrodes, electrode fouling, corrosion, and the possible formation of environmentally toxic intermediates [133].

Oxidation by ozonation can also effectively treat wastewater containing low concentrations of glyphosate in the shortest possible time. In this technology, two mechanisms of glyphosate oxidation are used: direct oxidation by ozone $\left(\mathrm{O}_{3}\right)$ or indirect oxidation by hydroxyl radicals [108]. Through this process, complete degradation of glyphosate by ozonation has also been achieved [134]. In addition, high glyphosate and AMPA removal efficiencies have been reported when using $\mathrm{O}_{3}$ and $\mathrm{H}_{2} \mathrm{O}_{2}$ simultaneously, in a short reaction time [135]. However, its application in practice is complicated because $\mathrm{O}_{3}$ is unstable under normal conditions, has low solubility in water, is expensive, and the mass transfer of $\mathrm{O}_{3}$ limits its performance [108].

Recently, the application of combined technologies has attracted the scientific community's attention, who are looking for more efficient alternatives for the degradation of glyphosate. For example, Xing et al. (2018) [136] reported 100\% removal of glyphosate in wastewater samples through the combined use of electrochemical oxidation and adsorption. Another option has been the combination of biological treatment and physicochemical 
processes for the treatment of water for drinking and rainwater with glyphosate residues. This alternative has been successfully employed in the treatment of polluted soils through biofilters that use plants [137] and microorganisms [138], with glyphosate removal efficiencies of 99 and $90 \%$, respectively. These combined processes represent interesting alternatives that could favor cost and efficiency in glyphosate degradation and therefore, further studies are required. As was highlighted, glyphosate-contaminated wastewater or soils could be efficiently treated with the technologies mentioned above, as they can degrade glyphosate and other pollutant molecules. However, to date, most of the tests have been at the laboratory level, so more studies are necessary to allow their implementation in real scenarios.

Another appropriate solution seems to be the use of bioremediation alternatives in which the use of microorganisms capable of degrading glyphosate into biologically safer compounds are employed to reduce environmental exposure risks.

\section{Glyphosate Biodegradation Alternatives}

Until recently, intensive use of the herbicide glyphosate was not considered an environmental risk, so research in the field of its bioremediation was limited [27]. However, the presence of glyphosate at different environmental matrixes has been related to human and ecosystem threats $[5,107,122]$. The environmental risks associated with glyphosate have driven the research and development of effective and environmentally friendly strategies for the cleaning and restoration of contaminated areas with the presence of this herbicide. In general, several methodologies, such as biological and physical methods, as well as advanced oxidation processes, have been successfully employed for glyphosate elimination [107,108,139].

Different authors have reported the degradation of glyphosate through different microorganisms such as bacteria, actinomycetes, and fungi; however, bacteria are the most reported microorganisms [102,108,140,141]. The biodegradation of glyphosate through the use of microorganisms has been considered a safe, low-cost, and reliable alternative to removing this xenobiotic from water and soil [140]. In this case, glyphosate degradation occurs because species of bacteria and fungi can use this compound as a source of nitrogen, carbon, and phosphorus, transforming it into new compounds through different degradation pathways [142,143]. Among the microorganisms (bacteria and fungi) used for the biological degradation of glyphosate are Achromobacter spp., Agrobacterium radiobacter, Alcaligenes sp. GL, Arthrobacter spp., Bacillus cereus CB4, Ochrobactrum spp., Pseudomonas spp., Aspergillus niger, Aspergillus oryzae A-F02, Penicillium chrysogenum, Trichoderma harzianum, among others [107]. The most common bacteria for glyphosate biodegradation are Pseudomonas spp. [144], which use glyphosate as a source of phosphorus [108]. It was recently documented that the employment of co-cultures of Pseudomonas sp. and Bacillus sp. is an effective strategy to degrade glyphosate in contaminated soils and aquifers since these bacteria can use glyphosate as the sole source of phosphorus [143]. Some disadvantages of biological treatments are that they cannot achieve high efficiency in the mineralization process due to the generation of by-products such as AMPA [141] or sarcosine [145], they require long periods of adequate growth time and conditions to achieve the highest degradation efficiencies $[107,141]$. In addition, for a more effective removal process, it is preferable for bacteria to use glyphosate as a source of carbon and not phosphorus since they have a greater demand for the former for their growth and metabolism [108]. Due to the generation of by-products, combining biological treatments with other processes can improve the efficiency of degradation of glyphosate and its metabolites.

\subsection{Bacterial Degradation of Glyphosate}

Different bacteria can metabolize glyphosate; its biodegradation generates the formation of metabolites that are used as a source of carbon, nitrogen, and phosphorus, elements that are essential for its development [146]. Bacteria can degrade glyphosate through two metabolic pathways. In the first pathway, the activity of the enzyme glyphosate oxidore- 
ductase (GOX) breaks the glyphosate molecule in two derived metabolites, the glyoxylate, which enters the tricarboxylic acid cycle and, as a result of its complete oxidation, generates carbon dioxide, and on the other hand, aminomethylphosphonic acid (AMPA), which with the help of the enzyme carbon-phosphorous lyase (C-P lyase) is hydrolyzed into phosphate and methylamine. The latter metabolite is transformed into ammonia (direct source of nitrogen) and formaldehyde that enters into the tetrahydrofolate (THFA) cycle. In the same pathway, through alternative reactions, AMPA is transformed with the help of the enzyme aminotransferase to phosphonoformaldehyde, which in turn is transformed by the enzyme phosphonatase into phosphate and formaldehyde which is also entered into the THFA pathway. The second pathway reported for the biodegradation of glyphosate involves the enzyme C-P lyase, which, through its hydrolytic activity, generates phosphate and sarcosine; in a subsequent step through the activity of the enzyme sarcosine oxidase, sarcosine is transformed into the amino acid glycine, which is used directly for metabolism and microbial biosynthesis, and formaldehyde that is entered into the THFA cycle [141]. To better understand the glyphosate biodegradation process, the interaction of glyphosate and AMPA with the key biodegradation enzymes GOX, and C-P lyase was studied through molecular docking and molecular dynamics. The results of these in silico experiments reveal the establishment of stable interactions of these metabolites with the active site of GOX and C-P lyase. Hydrogen bonds, van der Waals, and hydrophobic were prosed as the most important interactions [147]. In Figure 2, the main glyphosate biodegradation pathways in bacteria are shown.

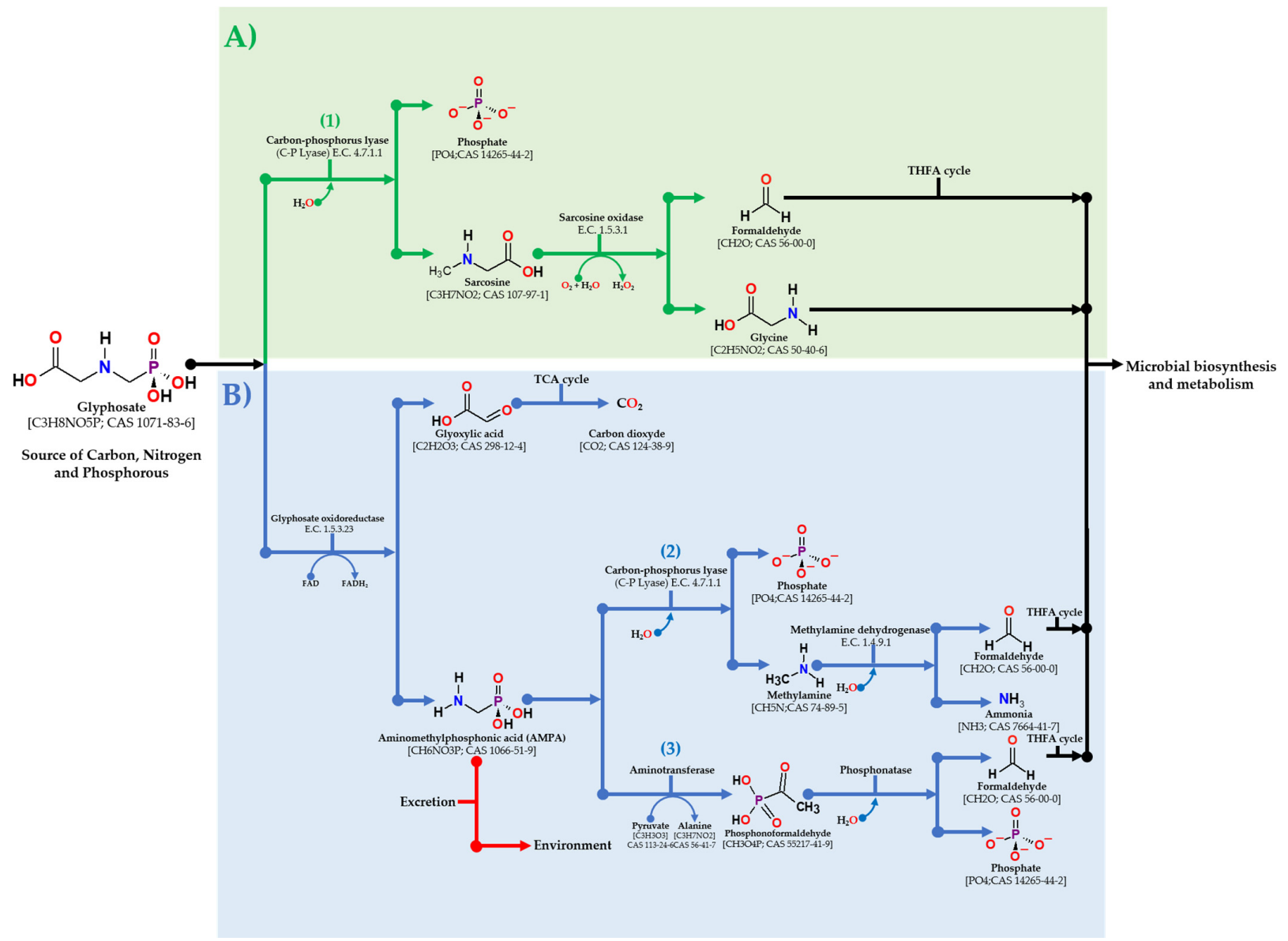

Figure 2. Principal glyphosate biodegradation pathways in bacteria. (A) Carbon-phosphorous lyase pathway (C-P lyase), (1) glyphosate degradation through sarcosine release as reported in Pseudomonas sp. PG2982 [148]. (B) Glyphosate oxidoreductase pathway (GOX pathway), (2) AMPA degradation in methylamine as reported in Arthrobacter sp. GLP-1 [149] and Flavobacterium sp. GD1 [150], and (3) alternative AMPA degradation pathway through the aminotransferase activity as reported in Ochrobactrum anthropi [151]. 
Table 1 lists recent studies related to bacterial-mediated degradation of glyphosate. In general, 28 species of bacteria were documented belonging to 13 genera with the capacity for glyphosate degradation. Their importance by the number of studies addressing them, shows the following pattern: Bacillus $>$ Ochrobactrum $>$ Agrobacterium $=$ Achromobacter $=$ Burkholderia $=$ Ensifer $=$ Pseudomonas $=$ Rhizobium $>$ Acidovorax $=$ Comamonas $=$ Lysinibacillus = Sinorhizobium $=$ Streptomycete. Overall, the herbicide degradation efficiency among the bacterial strains listed in Table 1, ranged from discrete percentages (37\%) to its complete degradation (100\%). Additionally, when data are organized into categories according to the bacterial degradation efficiency of glyphosate: low (37-58\%), intermediate (57-78\%), and high (79-100\%). According to the information shown in Table 1, the percentage of bacterial species belonging to each degradation category followed the next pattern: low $(39 \%)>$ high $(36 \%)>$ intermediate $(25 \%)$. The genera with lowest degradation efficiency for glyphosate were Ochrobactrum, Agrobacterium, Achromobacter, Bacillus, Pseudomonas, Rhizobium, Sinorhizobium, and Ensifer, and with intermediate degradation efficiency were Bacillus, Ochrobactrum, Pseudomonas, Bacillus, Burkholderia, and Achromobacter, and finally, the genera with the highest degradation efficiency were Lysinibacillus, Bacillus, Rhizobium, Streptomyces, Burkholderia, Comamonas, and Ochrobactrum. Only Pseudomonas aeruginosa and Bacillus cereus were classified into two levels for glyphosate degradation, intermediatelow and intermediate-high, respectively (Table 1). The fact that these two species were assigned to more than one glyphosate degradation category may be because both species were exposed to a wide range of glyphosate concentrations. Bacterial strains can degrade glyphosate through either the glyphosate oxidoreductase (GOX) pathway, the carbonphosphorus lyase (C-P lyase) pathway, or both (Table 1).

Table 1. Recent reports in microbial glyphosate degradation.

\begin{tabular}{|c|c|c|c|c|c|}
\hline Species & $\begin{array}{l}\text { Concentration } \\
(\mathrm{mg} / \mathrm{L})\end{array}$ & $\begin{array}{l}\text { Degradation } \\
(\%)\end{array}$ & System & Degradation Pathway $\S$ & Reference \\
\hline \multicolumn{6}{|c|}{ Bacteria } \\
\hline $\begin{array}{c}\text { Achromobacter denitrificans } \\
\text { SOS5 }\end{array}$ & \multirow{5}{*}{253} & 56 & \multirow{5}{*}{ In vitro } & glyphosate oxidoreductase & \multirow{5}{*}{ [152] } \\
\hline Achromobacter insolitus SOR2 & & 47 & & glyphosate oxidoreductase & \\
\hline $\begin{array}{c}\text { Achromobacter xylosoxidans } \\
\text { SOS3 }\end{array}$ & & 37 & & glyphosate oxidoreductase & \\
\hline $\begin{array}{c}\text { Agrobacterium tumefaciens } \\
\text { CHLDO }\end{array}$ & & 40 & & $\begin{array}{c}\text { glyphosate oxidoreductase } \\
\text { and C-P lyase }\end{array}$ & \\
\hline $\begin{array}{c}\text { Ochrobactrum haematophilum } \\
\text { SR }\end{array}$ & & 41 & & glyphosate oxidoreductase & \\
\hline Bacillus megaterium & $5-25$ & $70-71$ & In vitro & NR & [153] \\
\hline Acidovorax sp. CNI26 & \multirow{6}{*}{22.31} & \multirow{6}{*}{ NR } & \multirow{6}{*}{ In vitro } & C-P lyase & \multirow{6}{*}{ [139] } \\
\hline Agrobacterium tumefaciens & & & & glyphosate oxidoreductase & \\
\hline $\mathrm{CNI} 28$ & & & & and C-P lyase & \\
\hline Ensifer sp. CNI115 & & & & glyphosate oxidoreductase & \\
\hline Novosphingobium sp. CNI35 & & & & $\begin{array}{c}\text { glyphosate oxidoreductase } \\
\text { and C-P lyase }\end{array}$ & \\
\hline $\begin{array}{l}\text { Ochrobactrum pituitosum } \\
\text { CNI52 }\end{array}$ & & & & $\begin{array}{c}\text { glyphosate oxidoreductase } \\
\text { and C-P lyase }\end{array}$ & \\
\hline Bacillus aryabhattai FACU & $\begin{array}{c}50,100,150,200 \\
\text { and } 250\end{array}$ & NR & In vitro & glyphosate oxidoreductase & [154] \\
\hline Comamonas odontotermitis P2 & 500 & 90 & In vitro & $\begin{array}{c}\text { glyphosate oxidoreductase } \\
\text { and C-P lyase }\end{array}$ & [155] \\
\hline $\begin{array}{c}\text { Ochrobactrum sp. } \\
\text { Pseudomonas citronellolis }\end{array}$ & 50 & 60 & In vitro & NR & [156] \\
\hline Bacillus cereus & 169 & 38 & In vitro & C-P lyase & [157] \\
\hline
\end{tabular}


Table 1. Cont.

\begin{tabular}{|c|c|c|c|c|c|}
\hline Species & $\begin{array}{l}\text { Concentration } \\
(\mathrm{mg} / \mathrm{L})\end{array}$ & $\begin{array}{l}\text { Degradation } \\
(\%)\end{array}$ & System & Degradation Pathway $\S$ & Reference \\
\hline Lysinibacillus sphaericus & $679 \mathrm{~g} / \mathrm{Kg}$ * & 79 & In situ & C-P lyase & [158] \\
\hline $\begin{array}{c}\text { Bacillus subtilis } \\
\text { Rhizobium leguminosarum } \\
\text { Streptomyces sp. }\end{array}$ & 250 & $\begin{array}{l}90 \\
88 \\
89\end{array}$ & In vitro & $\begin{array}{c}\text { glyphosate oxidoreductase } \\
\text { and C-P lyase }\end{array}$ & [159] \\
\hline $\begin{array}{c}\text { Bacillus cereus } \\
\text { Pseudomonas aeruginosa }\end{array}$ & $\begin{array}{c}3,100,7200 \text { and } \\
14,400\end{array}$ & $\begin{array}{l}86,73 \text { and } 57 \\
76,85 \text { and } 47\end{array}$ & In situ & $\begin{array}{c}\text { glyphosate oxidoreductase } \\
\text { and C-P lyase }\end{array}$ & [160] \\
\hline $\begin{array}{l}\text { Ochrobactrum intermedium } \\
\text { Sq20 }\end{array}$ & 500 & 100 & In vitro & C-P lyase & [145] \\
\hline $\begin{array}{c}\text { Burkholderia sp. AQ5-13 } \\
\text { Burkholderia vietnamiensis } \\
\text { AQ5-12 }\end{array}$ & 50 & $\begin{array}{l}91 \\
74\end{array}$ & In vitro & NR & [144] \\
\hline $\begin{array}{c}\text { Ensifer sp. AC01b } \\
\text { Rhizobium sp. SCAUS14 } \\
\text { Sinorhizobium saheli OP3-1 }\end{array}$ & 5072 & $\begin{array}{l}44 \\
41 \\
39\end{array}$ & In vitro & NR & [161] \\
\hline Achromobacter sp. MPK 7A & 500 & 60 & In vitro & C-P lyase & [162] \\
\hline & & Fungi & & & \\
\hline $\begin{array}{l}\text { Aspergillus 2B112 } \\
\text { Penicillium 4A21 } \\
\text { Trichoderma }\end{array}$ & 500 & $\begin{array}{c}60 \\
26 \\
8\end{array}$ & In vitro & $\begin{array}{c}\text { NR } \\
\text { glyphosate oxidoreductase } \\
\text { and C-P lyase } \\
\text { NR }\end{array}$ & [163] \\
\hline $\begin{array}{c}\text { Aspergillus flavus EFB01 } \\
\text { Aspergillus flavus JN-YG-3-5 } \\
\text { Aspergillus fumigatus } \\
\text { FJAT-31052 } \\
\text { Aspergillus niger APBSDSF96 } \\
\text { Penicillium simplicissimum } \\
\text { SNB-VECD11G } \\
\text { Trichoderma gamsii P2-18 }\end{array}$ & 100 & $\begin{array}{l}84.7 \\
84.8 \\
84.7\end{array}$ & In vitro & glyphosate oxidoreductase & [164] \\
\hline $\begin{array}{c}\text { Trichoderma harzianum } \\
\text { MT871998 }\end{array}$ & $\begin{array}{l}200,400,600,800 \\
\text { and } 1000\end{array}$ & 78.1 & In vitro & NR & [165] \\
\hline Aspergillus oryzae AM1 & 1690 & 57 & In vitro & glyphosate oxidoreductase & {$[166]$} \\
\hline Aspergillus oryzae A-F02 & 500 & 66.9 & In vitro & $\begin{array}{c}\text { glyphosate oxidoreductase } \\
\text { and C-P lyase }\end{array}$ & {$[142]$} \\
\hline \multicolumn{6}{|c|}{ Algae } \\
\hline Oscillatoria limnetica & $\begin{array}{c}5 \\
10 \\
15 \\
20\end{array}$ & $\begin{array}{l}85 \\
38 \\
27 \\
75\end{array}$ & In vitro & NR & {$[167]$} \\
\hline
\end{tabular}

$\S$ Microorganisms with the same reference share the same glyphosate biodegradation pathway unless otherwise listed. * Concentration expressed in grams of herbicide by kilogram of soil. NR: not reported.

\subsection{Fungal Degradation of Glyphosate}

A limited number of fungal genera such as Aspergillus, Fusarium, Penicillium, and Trichoderma have been reported with the ability to degrade the herbicide glyphosate and use it as a source of carbon, phosphorus, or nitrogen [142,166,168,169]. Kulikova et al. (2020) [169] report that the biodegradation of the herbicide can be carried out both with the formation of AMPA and sarcosine, the latter being the main degradation pathway. For their part, in the study of Njoku et al. (2020) [164] fungal strains were identified capable of degrading glyphosate; this study points out that the selected fungi biodegraded the herbicide through GOX pathway due to the presence of the AMPA metabolite, in exception 
of Aspergillus fumigatus FJAT-31052. Despite these studies, the metabolic processes related to the degradation of glyphosate in fungi have not been fully described. Therefore, it is necessary to continue researching to identify the enzymes involved and to evaluate the effects of the herbicide on these organisms [142]. The studies by Mesnage et al. (2020) and Guo et al. (2021) $[170,171]$ are examples of some approaches to understanding the effects of glyphosate on Aspergillus nidulans and Fusarium verticillioides, respectively, through transcriptomic approaches. Table 1 presents recent studies related to the fungal-mediated degradation of glyphosate. In general, 13 species of fungi were documented belonging to four genera with the capacity for glyphosate degradation; their importance by the number of studies addressing them, showed the following pattern: Aspergillus $>$ Trichoderma $=$ Penicillium > Trichoderma. Overall, the herbicide degradation efficiency among the fungi strains listed in Table 1, ranged from $8 \%$ to $87 \%$ in Trichoderma sp. and Aspergillus niger MT871999, respectively. Additionally, when data are organized into categories according to the fungi degradation efficiency of glyphosate, low (8-35\%), intermediate (36-63\%), and high (64-90\%), we detected that the percentage of fungi species belonging to each degradation category shows the following pattern: high $(62 \%)>$ low $(31 \%)>$ intermediate $(15 \%)$. The species with lowest degradation efficiency for glyphosate were Trichoderma sp., Aspergillus flavus EFB01, and Aspergillus 2B112, those with intermediate degradation efficiency were Aspergillus oryzae AM1 and Penicillium 4A21, and finally, the species with the highest degradation efficiency were Aspergillus oryzae A-F02, Trichoderma harzianum MT871998, Trichoderma gamsii P2-18, Aspergillus fumigatus FJAT-31052, Penicillium simplicissimum SNB-VECD11G, Aspergillus niger APBSDSF96, Aspergillus flavus JN-YG-3-5, and Aspergillus niger MT871999.

\subsection{Algae Degradation of Glyphosate}

Only the algae species Oscillatoria limnetica has been documented with the ability to degrade the glyphosate. Overall, the herbicide degradation efficiency ranged from $38 \%$ to $85 \%$, the degradation variation percentages of this particular species may be a consequence of its exposure to different glyphosate concentrations (Table 1). It is important to note that the low number of studies on degradation and bioremediation of glyphosate using algae, offers a window of opportunity to increase the number of analyses using algae species. Algae species may be a good study model for bioremediation strategies due to (i) its sensitivity to pollutants, (ii) they are considered cost-effective, (iii) rapid cell cycle (iv) tests can reach acute exposure in a few hours, (v) sublethal responses of chronic toxicity can be assessed within a very short period (days), (vi) algae responses are at population level and not just at individual cells, which makes it possible to infer the responses of subsequent generations. In addition, the bioremediation of environments impacted by glyphosate that promote a detrimental impact in all levels of biological organization has been identified as one of the pending challenges in environmental toxicology, therefore, we require to find new study models such as algae species with high potential for herbicide degradation that help to return to a healthy environment along with other bioremediation techniques.

According to the information shown in Table 1, bacteria is the most studied group of microorganisms for glyphosate biodegradation, with 14 reports, followed by fungi with 5 reports, and finally algae with just 1 report. The glyphosate maximum biodegradation efficiencies in bacteria ranged between 90 and $100 \%$, while in fungi and algae the maximum biodegradation efficiencies reached values below $90 \%$. Moreover, higher glyphosate concentrations have been evaluated in studies carried out in bacteria $(5-14,400 \mathrm{mg} / \mathrm{L})$, in comparison to fungi (100-1690 mg/L) and algae (5-20 mg/L). According to these reports, bacteria seem the group of microorganisms with the higher potential for the implementation of glyphosate biodegradation strategies.

\section{Conclusions and Future Perspectives}

Glyphosate is the herbicide most employed worldwide. Its mechanism of action over weeds is related to the inactivation of the enzyme EPSPS in the shikimate pathway 
and the subsequent inhibition of aromatic amino acids biosynthesis. The absence of this metabolic pathway in animals and humans led to the general belief of the safeness of glyphosate over non-target organisms. However, the accumulation of scientific evidence on the adverse effects of glyphosate and degradation metabolites (AMPA), over different organisms, including soil microorganisms, plants, insects, fishes, among other animals, humans included, highlighted the impact of the extensive use of glyphosate worldwide. These facts increase the relevance of the development of alternatives for its elimination from different polluted environments, as physicochemical and biological approaches. Bioremediation is a suitable alternative for the treatment of glyphosate-related pollution. Several microorganisms, bacteria, and fungi have great potential for the biodegradation of this herbicide. The present review condensed a recent reports of the use of microorganisms as alternatives for glyphosate degradation, the most important bacterial genera reported being Achromobacter, Bacillus, Burkholderia, Ochrobactrum, and others, while the genera Aspergillus and Trichoderma were the most important among fungi. Due to the inclusion of glyphosate as a probable carcinogen by the IARC, bioremediation studies of this herbicide will become more relevant in the next years. In summary, additional studies are needed to evaluate the presence and levels of glyphosate and its related metabolites in the environment. In the present review, several studies related to the evaluation of microorganisms for glyphosate biodegradation were identified. However, studies of the application of microorganisms in bioremediation strategies are limited. In situ studies on the application of these microorganisms in glyphosate remediation approaches are urgently needed. Fungi and algae are emerging groups of microorganisms reported in glyphosate biodegradation studies. There is a need to evaluate a higher number of fungal and algae species to establish the real potential of such microorganisms in glyphosate biodegradation. As future trends, studies applying the OMICs technologies could help to understand in a better way the mechanisms employed by such microorganisms for glyphosate degradation and the strategies employed to avoid its adverse metabolic effects.

Author Contributions: Conceptualization, E.T.-S., P.M.-G. and A.R.; writing-original draft preparation, M.L.C.-G., L.V.-C., M.E.R.-R. and A.R.; writing-review and editing, M.L.C.-G., E.T.-S., P.M.-G. and A.R.; funding acquisition, A.R. All authors have read and agreed to the published version of the manuscript.

Funding: This work was supported by the National Council for Science and Technology (CONACYT for its acronym in Spanish), through the project "Bioremediation of agricultural soils contaminated by glyphosate through bacterial biodegradation and the treatment of its residues" grant number 315903.

Institutional Review Board Statement: Not applicable.

Informed Consent Statement: Not applicable.

Data Availability Statement: Not applicable.

Conflicts of Interest: The authors declare no conflict of interest.

\section{References}

1. Tarazona, J.V.; Tiramani, M.; Reich, H.; Pfeil, R.; Istace, F.; Crivellente, F. Glyphosate toxicity and carcinogenicity: A review of the scientific basis of the European Union assessment and its differences with IARC. Arch. Toxicol. 2017, 91, 2723-2743. [CrossRef] [PubMed]

2. $\quad$ Myers, J.P.; Antoniou, M.N.; Blumberg, B.; Carroll, L.; Colborn, T.; Everett, L.G.; Hansen, M.; Landrigan, P.J.; Lanphear, B.P.; Mesnage, R.; et al. Concerns over use of glyphosate-based herbicides and risks associated with exposures: A consensus statement. Environ. Health. 2016, 15, 19. [CrossRef] [PubMed]

3. Duke, S.O. The history and current status of glyphosate. Pest. Manag. Sci. 2018, 74, 5. [CrossRef] [PubMed]

4. Botten, N.; Wood, L.J.; Werner, J.R. Glyphosate remains in forest plant tissues for a decade or more. For. Ecol. Manag. 2021, 493, 119259. [CrossRef]

5. Cuhra, M.; Bøhn, T.; Cuhra, P. Glyphosate: Too much of a good thing? Front. Environ. Sci. 2016, 4, 1-28. [CrossRef]

6. Zabalza, A.; Orcaray, L.; Fernández-Escalada, M.; Zulet-González, M.; Royuela, M. The pattern of shikimate pathway and phenylpropanoids after inhibition by glyphosate or quinate feeding in pea roots. Pestic. Biochem. Physiol. 2017, 141, 96-102. [CrossRef] 
7. Boocock, M.R.; Coggins, J.R. Kinetics of 5-enolpyruvylshikimate-3-phosphate synthase inhibition by glyphosate. FEBS Lett. 1983, 154, 127-133. [CrossRef]

8. Gill, J.P.K.; Sethi, N.; Mohan, A.; Datta, S.; Girdhar, M. Glyphosate toxicity for animals. Environ. Chem. Lett. 2018, 16, 401-426. [CrossRef]

9. Kanissery, R.; Gairhe, B.; Kadyampakeni, D.; Batuman, O.; Alferez, F. Glyphosate: Its environmental persistence and impact on crop health and nutrition. Plants 2019, 8, 499. [CrossRef]

10. Benbrook, C.M. Trends in glyphosate herbicide use in the United States and globally. Environ. Sci. Eur. 2016, 28, 3. [CrossRef] [PubMed]

11. Fritschi, L.; McLaughlin, J.; Sergi, C.M.; Calaf, G.M.; Le Curieux, F.; Zeise, L. Carcinogenicity of tetrachlorvinphos, parathion, malathion, diazinon, and glyphosate. Lancet. Oncol. 2015, 16, 490-491. [CrossRef]

12. Duke, S.O.; Powles, S.B. Glyphosate: A once-in-a-century herbicide. Pest. Manag. Sci. 2008, 64, 319-325. [CrossRef] [PubMed]

13. Dill, G.M.; Sammons, R.D.; Feng, P.C.C.; Kohn, F.; Kretzmer, K.; Mehrsheikh, A.; Bleeke, M.; Honegger, J.L.; Farmer, D.; Wright, D.; et al. Glyphosate: Discovery, development, applications and properties. In Glyphosate Resistance in Crops and Weeds: History, Development, and Management; Wiley: Hoboken, NJ, USA, 2010; pp. 1-33.

14. Mesnage, R.; Defarge, N.; Spiroux de Vendômois, J.; Seralini, G.E. Potential toxic effects of glyphosate and its commercial formulations below regulatory limits. Food Chem. Toxicol. 2015, 84, 133-153. [CrossRef] [PubMed]

15. Annett, R.; Habibi, H.R.; Hontela, A. Impacts of glyphosate and glyphosate-based herbicides on the freshwater environment. J. Appl. Toxicol. 2014, 34, 458-479. [CrossRef]

16. Martens, M.A.; Bleeke, M.S.; Leopold, V.A.; Farmer, D.R. Toxicology and human health risk assessment of polyethoxylated tallow amine surfactant used in glyphosate formulations. Regul. Toxicol. Pharmacol. 2019, 107, 104347. [CrossRef]

17. Mesnage, R.; Benbrook, C.; Antoniou, M.N. Insight into the confusion over surfactant co-formulants in glyphosate-based herbicides. Food Chem. Toxicol. 2019, 128, 137-145. [CrossRef]

18. Mertens, M.; Höss, S.; Neumann, G.; Afzal, J.; Reichenbecher, W. Glyphosate, a chelating agent relevant for ecological risk assessment? Environ. Sci. Pollut. Res. 2018, 25, 5298-5317. [CrossRef]

19. Golt, A.R.; Wood, L.J. Glyphosate-Based Herbicides Alter the Reproductive Morphology of Rosa acicularis (Prickly Rose). Front. Plant. Sci. 2021, 12, 1184. [CrossRef] [PubMed]

20. Borggaard, O.K.; Gimsing, A.L. Fate of Glyphosate in Soil and the Possibility of Leaching to Ground and Surface Waters: A Review. Pest. Manag. Sci. 2008, 64, 441-456. [CrossRef] [PubMed]

21. Battaglin, W.A.; Meyer, M.T.; Kuivila, K.M.; Dietze, J.E. Glyphosate and Its Degradation Product AMPA Occur Frequently and Widely in U.S. Soils, Surface Water, Groundwater, and Precipitation. J. Am. Water Resour. Assoc. 2014, 50, 275-290. [CrossRef]

22. Ruiz-Toledo, J.; Castro, R.; Rivero-Pérez, N.; Bello-Mendoza, R.; Sánchez, D. Occurrence of Glyphosate in Water Bodies Derived from Intensive Agriculture in a Tropical Region of Southern Mexico. Bull. Environ. Contam. Toxicol. 2014, 93, 289-293. [CrossRef] [PubMed]

23. Lupi, L.; Bedmar, F.; Puricelli, M.; Marino, D.; Aparicio, V.C.; Wunderlin, D.; Miglioranza, K.S. Glyphosate runoff and its occurrence in rainwater and subsurface soil in the nearby area of agricultural fields in Argentina. Chemosphere 2019, 225, 906-914. [CrossRef]

24. Bonansea, R.; Filippi, I.; Wunderlin, D.; Marino, D.; Ame, M. The fate of glyphosate and AMPA in a freshwater endorheic basin: An ecotoxicological risk assessment. Toxics 2018, 6, 3. [CrossRef] [PubMed]

25. Instituto Regional de Estudios en Sustancias Tóxicas (IRET). (2015). Base de Datos de Ingredientes Activos Importados en Centroamérica. Universidad Nacional. Costa Rica. Available online: http:/ / www.plaguicidasdecentroamerica.info/index.php/ base-de-datos/ingredientes-activos/306-glifosato (accessed on 1 October 2021).

26. Cuhra, M. Review of GMO safety assessment studies: Glyphosate residues in Roundup Ready crops is an ignored issue. Environ. Sci. Eur. 2015, 27, 20. [CrossRef]

27. Sviridov, A.V.; Shushkova, T.V.; Ermakova, I.T.; Ivanova, E.V.; Leontievsky, A.A. Glyphosate: Safety risks, biodegradation, and bioremediation. In Current Environmental Issues and Challenges; Springer: Berlin/Heidelberg, Germany, 2014; ordrecht; pp. 183-195.

28. Van Bruggen, A.H.C.; He, M.M.; Shin, K.; Mai, V.; Jeong, K.C.; Finckh, M.R.; Morris, J.G., Jr. Environmental and health effects of glyphosate. Sci. Total Environ. 2018, 616, 255-268. [CrossRef]

29. Travaglia, C.; Masciarelli, O.; Fortuna, J.; Marchetti, G.; Cardozo, P.; Lucero, M.; Zorza, E.; Luna, V.; Reinoso, H. Towards sustainable maize production: Glyphosate detoxification by Azospirillum sp. and Pseudomonas sp. Crop. Prot. 2015, 77, 102-109. [CrossRef]

30. Cassigneul, A.; Benoit, P.; Bergheaud, V.; Dumeny, V.; Etiévant, V.; Goubard, Y.; Maylin, A.; Justes, E.; Alletto, L. Fate of glyphosate and degradates in cover crop residues and underlying soil: A laboratory study. Sci. Total Environ. 2016, 545, 582-590. [CrossRef] [PubMed]

31. Sidoli, P.; Baran, N.; Angulo-Jaramillo, R. Glyphosate and AMPA adsorption in soils: Laboratory experiments and pedotransfer rules. Environ. Sci. Pollut. Res. 2016, 23, 5733-5742. [CrossRef]

32. Okada, E.; Costa, J.L.; Bedmar, F. Adsorption and mobility of glyphosate in different soils under no-till and conventional tillage. Geoderma 2016, 263, 78-85. [CrossRef] 
33. Sihtmäe, M.; Blinova, I.; Kunnis-Beres, K.; Kanarbik, L.; Heinlaan, M.; Kahru, A. Ecotoxicological effects of different glyphosate formulations. Appl. Soil Ecol. 2013, 72, 215-224. [CrossRef]

34. Gill, J.P.K.; Sethi, N.; Mohan, A. Analysis of the glyphosate herbicide in water, soil and food using derivatising agents. Environ. Chem. Lett. 2017, 15, 85-100. [CrossRef]

35. Maqueda, C.; Undabeytia, T.; Villaverde, J.; Morillo, E. Behaviour of glyphosate in a reservoir and the surrounding agricultural soils. Sci. Total Environ. 2017, 593, 787-795. [CrossRef]

36. Van Stempvoort, D.R.; Spoelstra, J.; Senger, N.D.; Brown, S.J.; Post, R.; Struger, J. Glyphosate residues in rural groundwater, Nottawasaga River watershed, Ontario, Canada. Pest Manag. Sci. 2016, 72, 1862-1872. [CrossRef] [PubMed]

37. Rendón-von Osten, J.; Dzul-Caamal, R. Glyphosate residues in groundwater, drinking water and urine of subsistence farmers from intensive agriculture localities: A survey in Hopelchén, Campeche, Mexico. Int. J. Environ. Res. Public Health 2017, 14, 595. [CrossRef] [PubMed]

38. Yang, X.; Wang, F.; Bento, C.P.M.; Xue, S.; Gai, L.; van Dam, R.; Mol, H.; Ritsema, C.J.; Geissen, V. Short-term transport of glyphosate with erosion in Chinese loess soil-a flume experiment. Sci. Total Environ. 2015, 512, 406-414. [CrossRef]

39. Alonso, L.L.; Demetrio, P.M.; Etchegoyen, M.A.; Marino, D. Glyphosate and atrazine in rainfall and soils in agroproductive areas of the pampas region in Argentina. Sci. Total Environ. 2018, 645, 89-96. [CrossRef] [PubMed]

40. Silva, V.; Montanarella, L.; Jones, A.; Fernandez-Ugalde, O.; Mol, H.G.J.; Ritsema, C.J.; Geissen, V. Distribution of glyphosate and aminomethylphosphonic acid (AMPA) in agricultural topsoils of the European Union. Sci. Total Environ. 2018, 621, 1352-1359. [CrossRef] [PubMed]

41. Chang, F.C.; Simcik, M.F.; Capel, P. Occurrence and fate of the herbicide glyphosate and its degradate aminomethylphosphonic acid in the atmosphere. Environ. Toxicol. Chem. 2011, 30, 548-555. [CrossRef]

42. Mercurio, P.; Flores, F.; Mueller, J.F.; Carter, S.; Negri, A.P. Glyphosate persistence in seawater. Mar. Pollut. Bull. 2014, 85, 385-390. [CrossRef]

43. WHO (World Health Organization) Glyphosate and AMPA in Drinking-Water. 2005. Available online: http://www.who.int/wa ter_sanitation_health/dwq/chemicals/glyphosateampa290605.pdf (accessed on 7 September 2021).

44. Meena, R.S.; Kumar, S.; Datta, R.; Lal, R.; Vijayakumar, V.; Brtnicky, M.; Sharma, M.P.; Yadav, G.S.; Jhariya, M.K.; Jangir, C.K.; et al. Impact of agrochemicals on soil microbiota and management: A review. Land 2020, 9, 34. [CrossRef]

45. Sterren, M.; Uhrich, W.; Benintende, S. Residualidad de glifosato en suelos de Entre Ríos y su efecto sobre los microorganismos del suelo. Ecología Austral. 2016, 26, 46-255. [CrossRef]

46. Helander, M.; Saloniemi, I.; Omacini, M.; Druille, M.; Salminen, J.P.; Saikkonen, K. Glyphosate decreases mycorrhizal colonization and affects plant-soil feedback. Sci. Total Environ. 2018, 642, 285-291. [CrossRef] [PubMed]

47. Vázquez, M.B.; Moreno, M.V.; Amodeo, M.R.; Bianchinotti, M.V. Effects of glyphosate on soil fungal communities: A field study. Rev. Argent. Microbiol. 2021. [CrossRef]

48. Correia, F.V.; Moreira, J.C. Effects of glyphosate and 2, 4-D on earthworms (Eisenia foetida) in laboratory tests. Bull. Environ. Contam. Toxicol. 2010, 85, 264-268. [CrossRef] [PubMed]

49. Piola, L.; Fuchs, J.; Oneto, M.L.; Basack, S.; Kesten, E.; Casabe, N. Comparative toxicity of two glyphosate-based formulations to Eisenia andrei under laboratory conditions. Chemosphere 2013, 91, 545-551. [CrossRef] [PubMed]

50. García-Torre, T.; Giufre, L.; Romaniuk, R.; Rios, R.P.; Pagano, E.A. Exposure assessment to glyphosate of two species of annelids. Bull. Environ. Contam. Toxicol. 2014, 93, 209-214. [CrossRef]

51. Hagner, M.; Mikola, J.; Saloniemi, I.; Saikkonen, K.; Helander, M. Effects of a glyphosate-based herbicide on soil animal trophic groups and associated ecosystem functioning in a northern agricultural field. Sci. Rep. 2019, 9, 8540. [CrossRef]

52. Gomes, M.P.; Manaćh, L.; Sarah, G.; Henault-Ethier, L.; Labrecque, M.; Lucotte, M.; Juneau, P. Glyphosate-dependent inhibition of photosynthesis in willow. Front. Plant Sci. 2017, 8, 207. [CrossRef]

53. Van Bruggen, A.H.C.; Finckh, M.R. Plant diseases and management approaches in organic farming systems. Annu. Rev. Phytopathol. 2016, 54, 25-54. [CrossRef]

54. Li, M.H.; Ruan, L.Y.; Zhou, J.W.; Fu, Y.H.; Jiang, L.; Zhao, H.; Wang, J.S. Metabolic profiling of goldfish (Carassius auratis) after long-term glyphosate based herbicide exposure. Aquat. Toxicol. 2017, 188, 159-169. [CrossRef]

55. Moreno, N.C.; Sofia, S.H.; Martinez, C.B.R. Genotoxic effects of the herbicide Roundup Transorb®and its active ingredient glyphosate on the fish Prochilodus lineatus. Eviron. Toxicol. Pharmacol. 2014, 37, 448-454. [CrossRef] [PubMed]

56. Caramello, C.S.; Jorge, M.J.; Jorge, N.L.; Jorge, L.C. Evaluation of herbicide glyphosate effects in the fish Prochilodus lineatus using chromosome aberration test. Rev. Vet. 2017, 28, 65-68. [CrossRef]

57. Kreutz, L.C.; Gil Barcellos, L.J.; Marteninghe, E.; Davidos Santos, E.; Zanatta, R. Exposure to sublethal concentration of glyphosate or atrazine-based herbicides alters the phagocytic function and increases the susceptibility of silver catfish fingerlings (Rhamdia quelen) to Aeromonas hydrophila challenge. Fish Shellfish. Immunol. 2010, 29, 694-697. [CrossRef] [PubMed]

58. Kreutz, L.C.; Gil Barcellos, L.J.; Valle, S.F.; Silva, T.O.; Anziliero, D.; Davidos Santos, E.; Pivato, M.; Zanatta, R. Altered hematological and immunological parameters in silver catfish (Rhamdia quelen) following short term exposure to sublethal concentration of glyphosate. Fish Shellfish. Immunol. 2011, 30, 51-57. [CrossRef]

59. Balbuena, M.S.; Tison, L.; Hahn, M.L.; Greggers, U.; Menzel, R.; Farina, W.M. Effects of sublethal doses of glyphosate on honeybee navigation. J. Exp. Biol. 2015, 218, 2799-2805. [CrossRef] [PubMed] 
60. Samsel, A.; Seneff, S. Glyphosate's suppression of cytochrome P450 enzymes and amino acid biosynthesis by the gut microbiome: Pathways to modern diseases. Entroy 2013, 15, 1416-1463. [CrossRef]

61. Gandhi, K.; Khan, S.; Patrikar, M.; Markad, A.; Kumar, N.; Choudhari, A.; Sagar, P.; Indurkar, S. Exposure risk and environmental impacts of glyphosate: Highlights on the toxicity of herbicide co-formulants. Environ. Chall. 2021, 4, 100149. [CrossRef]

62. Gillezeau, C.; Van Gerwen, M.; Shaffer, R.; Rana, I.; Zhang, L.; Sheppard, L.; Taioli, E. The evidence of human exposure to glyphosate: A review. Environ. Health 2019, 18, 2. [CrossRef]

63. WHO Europe. Results of Joint FAO/WHO Meeting on Pesticide Residues (JMPR). $2016 . \quad$ Available online: https: //www.euro.who.int/en/health-topics/disease-prevention/food-safety/news/news/2016/05/results-of-joint-faowho -meeting-on-pesticide-residues-jmpr (accessed on 1 October 2021).

64. Duke, S.O. Overview of herbicide mechanisms of action. Environ. Health Perspect. 1990, 87, 263-271. [CrossRef]

65. Mann, R.M.; Bidwell, J.R. The toxicity of glyphosate and several glyphosate formulations to four species of southwestern Australian frogs. Arch. Environ. Contam. Toxicol. 1999, 36, 193-199. [CrossRef]

66. Williams, G.M.; Kroes, R.; Munro, I.C. Safety evaluation and risk assessment of the herbicide Roundup and its active ingredient, glyphosate, for humans. Regul. Toxicol. Pharmacol. 2000, 31, 117-165. [CrossRef]

67. Gress, S.; Lemoine, S.; Séralini, G.E.; Puddu, P.E. Glyphosate-based herbicides potently affect cardiovascular system in mammals: Review of the literature. Cardiovasc. Toxicol. 2015, 15, 117-126. [CrossRef]

68. IARC. Glyphosate. In Some Organophosphate Insecticides and Herbicides: Diazinon, Glyphosate, Malathion, Parathion, Tetrachlorvinphos. IARC Working Group, 3-10 March 2015; World Health Organization (WHO), International Agency for Research on Cancer (IARC) (IARC Monographs on the Evaluation of Carcinogen Risks to Humans): Lyon, France, 2015; Volume 112, pp. 1-92. Available online: http:/ / monographs.iarc.fr/ENG/Monographs/vol112/index.php (accessed on 1 October 2021).

69. Bai, S.H.; Ogbourne, S.M. Glyphosate: Environmental contamination, toxicity and potential risks to human health via food contamination. Environ. Sci. Pollut. Res. 2016, 23, 18988-19001. [CrossRef] [PubMed]

70. Arellano-Aguilar, O.; Montero-Montoya, R. Glifosato y los cultivos transgénicos en México. In Los plaguicidas altamente peligrosos en México; Bejarano-González, F., Ed.; Red de Acción sobre Plaguicidas y Alternativas en México, A.C. (RAPAM): Estado de México, México, 2015; pp. 153-166.

71. Samsel, A.; Seneff, S. Glyphosate, pathways to modern diseases II: Celiac sprue and gluten intolerance. Interdiscip. Toxicol. 2013, 6, 159-184. [CrossRef]

72. Schinasi, L.; Leon, M.E. Non-Hodgkin lymphoma and occupational exposure to agricultural pesticide chemical groups and active ingredients: A systematic review and meta-analysis. Int. J. Environ. Res. Public. Health. 2014, 11, 4449-4527. [CrossRef]

73. Henneberger, P.K.; Liang, X.; London, S.J.; Umbach, D.M.; Sandler, D.P.; Hoppin, J.A. Exacerbation of symptoms in agricultural pesticide applicators with asthma. Int. Arch. Occup. Environ. Health 2014, 87, 423-432. [CrossRef] [PubMed]

74. Zouaoui, K.; Dulaurent, S.; Gaulier, J.M.; Moesch, C.; Lachatre, G. Determination of glyphosate and AMPA in blood and urine from humans: About cases of acute intoxication. Forensic. Sci. Int. 2013, 226, 20-25. [CrossRef] [PubMed]

75. Beecham, J.E.; Seneff, S. The possible link between autism and glyphosate acting as glycine mimetic-A review of evidence from the literature with analysis. J. Mol. Genet. Med. 2015, 9, 1000197. [CrossRef]

76. Young, F.; Ho, D.; Glynn, D.; Edwards, V. Endocrine disruption and cytotoxicity of glyphosate and roundup in human JAr cells in vitro. Integr. Pharm. Toxicol. Gentocicol. 2015, 1, 12-19. [CrossRef]

77. Peillex, C.; Pelletier, M. The impact and toxicity of glyphosate and glyphosate-based herbicides on health and immunity. $J$. Immunotoxicol. 2020, 17, 163-174. [CrossRef]

78. Weisenburger, D.D. A review and update with perspective of evidence that the herbicide glyphosate (Roundup) is a Cause of non-Hodgkin lymphoma. Clin. Lymphoma Myeloma Leuk. 2021, 21, 621-630. [CrossRef]

79. Venugopal, K.; Suresh, C.; Vishwanath, H.; Lingaraja, M.; Bharath Raj, M.Y. Glyphosate: Surfactant herbicide poisoning-Is it mild? Med. J. DY. Patil. Univ. 2015, 8, 816-818. [CrossRef]

80. Melo, K.; De Nucci, G.; Trape, A.; Jacobucci, S.; Garlipp, C.; Rosa, P. Brief review analytical methods for the determination of glyphosate. MOJ Toxicol. 2018, 4, 39-42. [CrossRef]

81. Singh, S.; Kumar, V.; Datta, S.; Wani, A.B.; Dhanjal, D.S.; Romero, R.; Singh, J. Glyphosate uptake, translocation, resistance emergence in crops, analytical monitoring, toxicity, and degradation: A review. Environ. Chem. 2020, 18, 663-702. [CrossRef]

82. Ansari, M.; Sedighi-Khavida, S.; Hatami, B. Toxicity, Biodegradability and Detection Methods of Glyphosate; the Most Used Herbicide: A Systematic Review. J. Environ. Health Sustain. Dev. 2019, 4, 731-743. [CrossRef]

83. Arkan, T.; Molnár-Perl, I. The role of derivatization techniques in the analysis of glyphosate and aminomethyl-phosphonic acid by chromatography. Microchem. J. 2015, 121, 99-106. [CrossRef]

84. Kawai, S.; Uno, B.; Tomita, M. Determination of glyphosate and its major metabolite aminomethyl phosphonic acid by highperformance liquid chromatography alter derivatization with p-toluenesulphonyl chloride. J. Chromatogr. A 1991, 540, 411-415. [CrossRef]

85. Sancho, J.V.; Hernández, F.; López, F.J.; Hognedoom, E.A.; Dijkman, E. Rapid determination of glufosinate, glyphosate, and aminomethylphosphonic acid in environmental water samples using precolumn fluorogenic labeling and coupled-column liquid chromatography. J. Chromatogr. A 1996, 737, 75-83. [CrossRef]

86. Nedelkoska, T.V.; Low, G.K.C. High-performance liquid chromatographic determination of glyphosate in water and plant material after pre-column derivatisation with 9-fluorenylmethyl chloroformate. Anal Chim. Acta 2004, 511, 45-153. [CrossRef] 
87. Fang, F.; Wei, R.; Liu, X. Novel pre-column derivatisation reagent for glyphosate by high-performance liquid chromatography and ultraviolet detection. Int. J. Environ. Anal. Chem. 2014, 94, 661-667. [CrossRef]

88. De Almeida, L.; Chigome, S.; Torto, N.; Frost, C.; Pletschke, B. A novel colorimetric sensor strip for the detection of glyphosate in water. Sens. Actuators B Chem. 2015, 206, 357-363. [CrossRef]

89. Goodwin, L.; Hanna, M.; Startin, J.R.; Keely, B.J.; Goodall, D.M. Isotachophoretic separation of glyphosate, glufosinate, AMPA and MPP with contactless conductivity detection. Analyst 2002, 127, 204-206. [CrossRef]

90. You, J.; Koropchak, J.A. Condensation nucleation light scattering detection with ion chromatography for direct determination of glyphosate and its metabolite in water. J. Chromatogr. A 2003, 989, 231-238. [CrossRef]

91. Guo, Z.X.; Cai, Q.; Yang, Z. Ion chromatography/inductively coupled plasma mass spectrometry for simultaneous determination of glyphosate, glufosinate, fosamine and ethephon at nanogram levels in water. Rapid Commun. Mass Spectrom. 2007, 21, 1606-1612. [CrossRef]

92. Chen, Y.; Wu, F.; Lin, Y.X.; Deng, N.; Bazhin, N.; Glebov, E. Photodegradation of glyphosate in the ferrioxalate system. J. Hazard. Mater. 2007, 148, 360-365. [CrossRef]

93. Songa, E.A.; Somerset, V.S.; Waryo, T.; Baker, P.G.L.; Iwuoha, E.I. Amperometric nanobiosensor for quantitative determination of glyphosate and glufosinate residues in corn samples. Pure Appl. Chem. 2009, 81, 123-139. [CrossRef]

94. Sanchís, J.; Kantiani, L.; Llorca, M.; Rubio, F.; Ginebreda, A.; Fraile, J.; Garrido, T.; Farré, M. Determination of Glyphosate in Groundwater Samples Using an Ultrasensitive Immunoassay and Confirmation by On-Line Solid-Phase Extraction Followed by Liquid Chromatography Coupled to Tandem Mass Spectrometry. Anal. Bioanal. Chem. 2012, 402, 2335-2345. [CrossRef] [PubMed]

95. Chuang, H.Y.; Hong, T.P.; Whang, C.W. A simple and rapid screening method for glyphosate in water using fow-injection with electrochemiluminescence detection. Anal. Methods 2013, 5, 6186-6191. [CrossRef]

96. Mörtl, M.; Németh, G.; Juracsek, J.; Darvas, B.; Kamp, L.; Rubio, F.; Székács, A. Determination of glyphosate residues in Hungarian water samples by immunoassay. Microchem. J. 2013, 107, 143-151. [CrossRef]

97. Krüger, M.; Schledorn, P.; Schrödl, W.; Hoppe, H.W.; Lutz, W.; Shehata, A.A. Detection of glyphosate residues in animals and humans. J. Environ. Anal. Toxicol. 2014, 4, 1-5. [CrossRef]

98. Chang, Y.; Zhang, Z.; Hao, J.; Yang, W.; Tang, J. A simple label free colorimetric method for glyphosate detection based on the inhibition of peroxidase-like activity of Cu (II). Sens. Actuators B Chem. 2016, 228, 410-415. [CrossRef]

99. Wang, S.; Seiwert, B.; Kästner, M.; Miltner, A.; Schäffer, A.; Reemtsma, T.; Yang, Q.; Nowak, K.M. (Bio)degradation of glyphosate in water-sediment microcosms-A stable isotope co-labeling approach. Water. Res. 2016, 99, 91-100. [CrossRef] [PubMed]

100. Koskinen, W.C.; Marek, L.J.; Hall, K.E. Analysis of glyphosate and aminomethylphosphonic acid in water, plant materials and soil. Pest. Manag. Sci. 2016, 72, 423-432. [CrossRef]

101. Valle, A.L.; Mello, F.C.C.; Alves-Balvedi, R.P.; Rodrigues, L.P.; Goulart, L.R. Glyphosate detection: Methods, needs and challenges. Environ. Chem. Lett. 2019, 17, 291-317. [CrossRef]

102. ATSDR. Toxicological Profile of Glyphosate; Agency for Toxic Substances and Disease Registry, the Public Health Service, or the U.S Department of Health and Human Services: Atlanta, GA, USA, 2020. Available online: https://www.atsdr.cdc.gov/toxprofiles/t p214.pdf (accessed on 1 October 2021).

103. Antier, C.; Kudsk, P.; Reboud, X.; Ulber, L.; Baret, P.V.; Messéan, A. Glyphosate use in the European agricultural sector and a framework for its further monitoring. Sustainability 2020, 12, 5682. [CrossRef]

104. Richmond, M.E. Glyphosate: A review of its global use, environmental impact, and potential health effects on humans and other species. J. Environ. Stud. Sci. 2018, 8, 416-434. [CrossRef]

105. Singh, S.; Kumar, V.; Gill, J.P.K.; Datta, S.; Singh, S.; Dhaka, V.; Kapoor, D.; Wani, A.B.; Dhanjal, D.S.; Kumar, M.; et al. Herbicide glyphosate: Toxicity and microbial degradation. Int. J. Environ. Res. Public Health 2020, 17, 7519. [CrossRef]

106. Pérez, G.L.; Vera, M.S.; Miranda, L. Effects of Herbicide Glyphosate and Glyphosate-Based Formulations on Aquatic Ecosystems. In Herbicides and Environment; Kortekamp, A., Ed.; InTech Publications: Rijeka, Croatia, 2011.

107. Espinoza-Montero, P.J.; Vega-Verduga, C.; Alulema-Pullupaxi, P.; Fernández, L.; Paz, J.L. Technologies employed in the treatment of water contaminated with glyphosate: A Review. Molecules 2020, 25, 5550. [CrossRef] [PubMed]

108. Feng, D.; Soric, A.; Boutin, O. Treatment technologies and degradation pathways of glyphosate: A critical review. Sci. Total Environ. 2020, 742, 140559. [CrossRef]

109. Li, F.; Wang, Y.; Yang, Q.; Evans, D.G.; Forano, C.; Duan, X. Study on adsorption of glyphosate (N-phosphonomethyl glycine) pesticide on Mg Al-layered double hydroxides in aqueous solution. J. Hazard. Mater. 2005, 125, 89-95. [CrossRef]

110. Nourouzi, M.M.; Chuah, T.G.; Choong, T.S.Y. Adsorption of glyphosate onto activated carbon derived from waste newspaper. Desalination. Water. Treat. 2010, 24, 321-326. [CrossRef]

111. Salman, J.M.; Abid, F.M.; Muhammed, A.A. Batch study for pesticide glyphosate adsorption onto palm oil fronds activated carbon. Asian. J. Chem. 2012, 24, 5646-5648.

112. Zavareh, S.; Farrokhzad, Z.; Darvishi, F. Modification of zeolite 4 A for use as an adsorbent for glyphosate and as an antibacterial agent for water. Ecotoxicol. Environ. Saf. 2018, 155, 1-8. [CrossRef] [PubMed]

113. Herath, I.; Kumarathilaka, P.; Al-Wabel, M.I.; Abduljabbar, A.; Ahmad, M.; Usman, A.R.A.; Vithanage, M. Mechanistic modeling of glyphosate interaction with rice husk derived engineered biochar. Microporous Mesoporous Mater. 2016, 225, 280-288. [CrossRef]

114. Jia, D.M.; Li, C.H.; Li, A.M. Effective removal of glyphosate from water by double valent nano-sized hydroxyl iron oxide. RSC Adv. 2017, 7, 24430-24437. [CrossRef] 
115. Li, Y.; Zhao, C.; Wen, Y.; Wang, Y.; Yang, Y. Adsorption performance and mechanism of magnetic reduced graphene oxide in glyphosate contaminated water. Environ. Sci. Pollut. Res. 2018, 25, 21036-21048. [CrossRef] [PubMed]

116. Rissouli, L.; Benicha, M.; Chafik, T.; Chabbi, M. Decontamination of water polluted with pesticide using biopolymers: Adsorption of glyphosate by chitin and chitosan. J. Mater. Environ. Sci. 2017, 8, 4544-4549. [CrossRef]

117. Xiao, G.; Meng, Q. D151 resin preloaded with Fe3+ as a salt resistant adsorbent for glyphosate from water in the presence $16 \%$ NaCl. Ecotoxicol. Environ. Saf. 2020, 190, 110140. [CrossRef]

118. Liu, Z.Y.; Xie, M.; Ni, F.; Xu, Y.H. Nanofiltration process of glyphosate simulated wastewater. Water Sci. Technol. 2012, 65, 816-822. [CrossRef]

119. Yuan, J.; Duan, J.; Saint, C.P.; Mulcahy, D. Removal of glyphosate and aminomethylphosphonic acid from synthetic water by nanofiltration. Environ. Technol. 2018, 39, 1384-1392. [CrossRef]

120. Hosseini, N.; Toosi, M.R. Removal of 2,4-D, glyphosate, trifluralin, and butachlor herbicides from water by polysulfone membranes mixed by graphene oxide/TiO nanocomposite: Study of filtration and batch adsorption. J. Environ. Health Sci. Eng. 2019, 17, 247-258. [CrossRef] [PubMed]

121. Wang, J.L.; Xu, L. Advanced oxidation processes for wastewater treatment: Formation of hydroxyl radical and application. Crit. Rev. Environ. Sci. Technol. 2012, 42, 251-325. [CrossRef]

122. Villamar-Ayala, C.A.; Carrera-Cevallos, J.V.; Vasquez-Medrano, R.; Espinoza-Montero, P.J. Fate, eco-toxicological characteristics, and treatment processes applied to water polluted with glyphosate: A critical review. Crit. Rev. Environ. Sci. Technol. 2019, 49, 1476-1514. [CrossRef]

123. Bokare, A.D.; Choi, W. Review of iron-free Fenton-like systems for activating $\mathrm{H}_{2} \mathrm{O}_{2}$ in advanced oxidation processes. J. Hazard. Mater. 2014, 275, 121-135. [CrossRef] [PubMed]

124. Zhang, M.H.; Dong, H.; Zhao, L.; Wang, D.X.; Meng, D. A review on Fenton process for organic wastewater treatment based on optimization perspective. Sci. Total. Environ. 2019, 670, 110-121. [CrossRef] [PubMed]

125. Deng, Y.; Zhao, R. Advanced Oxidation Processes (AOPs) in Wastewater Treatment. Curr. Pollut. Rep. 2015, 1, 167-176. [CrossRef]

126. Souza, D.R.; Trovó, A.G.; Filho, A.R.N.; Silva, M.A.A.; Machado, A.E.H. Degradation of the commercial herbicide glyphosate by photo-Fenton process: Evaluation of kinetic parameters and toxicity. J. Braz. Chem. Soc. 2013, 24, 1451-1460. [CrossRef]

127. Rubí-Juárez, H.; Cotillas, S.; Sáez, C.; Cañizares, P.; Barrera-Díaz, C.; Rodrigo, M.A. Removal of herbicide glyphosate by conductive-diamond electrochemical oxidation. Appl. Catal. B Environ. 2016, 188, 305-312. [CrossRef]

128. Tran, N.; Drogui, P.; Doan, T.L.; Le, T.S.; Nguyen, H.C. Electrochemical degradation and mineralization of glyphosate herbicide. Environ. Technol. 2017, 38, 2939-2948. [CrossRef]

129. Comninellis, C.; Chen, G. Electrochemistry for the Environment; Springer: New York, NY, USA, 2010.

130. Lan, H.; Jiao, Z.; Zhao, X.; He, W.; Wang, A.; Liu, H.; Liu, R.; Qu, J. Removal of glyphosate from water by electrochemically assisted MnO2 oxidation process. Sep. Purif. Technol. 2013, 117, 30-34. [CrossRef]

131. Farinos, R.M.; Ruotolo, L.A.M. Comparison of the electrooxidation performance of three-dimensional RVC/PbO2 and borondoped diamond electrodes. Electrochim. Acta 2017, 224, 32-39. [CrossRef]

132. Kukurina, O.; Elemesova, Z.; Syskina, A. Mineralization of organophosphorous pesticides by electro-generated oxidants. Procedia Chem. 2014, 10, 209-216. [CrossRef]

133. Sánchez-Montes, I.; Pérez, J.F.; Sáez, C.; Rodrigo, M.A.; Cañizares, P.; Aquino, J.M. Assessing the performance of electrochemical oxidation using DSA®and BDD anodes in the presence of UVC light. Chemosphere 2020, 238, 124575. [CrossRef]

134. Assalin, M.R.; De Moraes, S.G.; Queiroz, S.C.N.; Ferracini, V.L.; Duran, N. Studies on degradation of glyphosate by several oxidative chemical processes: Ozonation, photolysis and heterogeneous photocatalysis. J. Environ. Sci. Health. Part B Pestic. Food Contam. Agric. Wastes 2009, 45, 89-94. [CrossRef] [PubMed]

135. Jönsson, J.; Camm, R.; Hall, T. Removal and degradation of Glyphosate in water treatment: A review. J. Water Supply Res. Technol. AQUA 2013, 62, 395-408. [CrossRef]

136. Xing, B.; Chen, H.; Zhang, X. Efficient degradation of organic phosphorus in glyphosate wastewater by catalytic wet oxidation using modified activated carbon as a catalyst. Environ. Technol. 2018, 39, 749-758. [CrossRef]

137. Yang, H.; Dick, W.A.; McCoy, E.L.; Phelan, P.L.; Grewal, P.S. Field evaluation of a new biphasic rain garden for stormwater flow management and pollutant removal. Ecol. Eng. 2013, 54, 22-31. [CrossRef]

138. Zhang, K.; Deletic, A.; Page, D.; McCarthy, D.T. Surrogates for herbicide removal in stormwater biofilters. Water Res. 2015, 81, 64-71. [CrossRef]

139. Rossi, F.; Carles, L.; Donnadieu, F.; Batisson, I.; Artigas, J. Glyphosate-degrading behavior of five bacterial strains isolated from stream biofilms. J. Hazard Mater. 2021, 420, 126651. [CrossRef]

140. Sviridov, A.V.; Shushkova, T.V.; Ermakova, I.T.; Ivanova, E.V.; Epiktetov, D.O.; Leontievsky, A.A. Microbial degradation of glyphosate herbicides. Appl. Biochem. Microbiol. 2015, 51, 188-195. [CrossRef]

141. Zhan, H.; Feng, Y.; Fan, X.; Chen, S. Recent advances in glyphosate biodegradation. Appl. Microbiol. Biotechnol. 2018, 102, 5033-5043. [CrossRef] [PubMed]

142. Fu, G.M.; Chen, Y.; Li, R.Y.; Yuan, X.Q.; Liu, C.M.; Li, B.; Wan, Y. Pathway and rate-limiting step of glyphosate degradation by Aspergillus oryzae A-F02. Prep. Biochem. Biotechnol. 2017, 47, 782-788. [CrossRef] [PubMed]

143. Wijekoon, N.; Yapa, N. Assessment of plant growth promoting rhizobacteria (PGPR) on potential biodegradation of glyphosate in contaminated soil and aquifers. Groundw. Sustain. Dev. 2018, 7, 465-469. 
144. Manogaran, M.; Ahmad, S.A.; Yasid, N.A.; Yakasai, H.M.; Shukor, M.Y. Characterisation of the simultaneous molybdenum reduction and glyphosate degradation by Burkholderia vietnamiensis AQ5-12 and Burkholderia sp. AQ5-13. 3 Biotech 2018, 8, 1-8. [CrossRef] [PubMed]

145. Firdous, S.; Iqbal, S.; Anwar, S.; Jabeen, H. Identification and analysis of 5-enolpyruvylshikimate-3-phosphate synthase (EPSPS) gene from glyphosate-resistant Ochrobactrum intermedium Sq20. Pest Manag. Sci. 2018, 74, 1184-1196. [CrossRef]

146. Hove-Jensen, B.; Zechel, D.L.; Jochimsen, B. Utilization of glyphosate as phosphate source: Biochemistry and genetics of bacterial carbon-phosphorus lyase. Microbiol. Mol. Biol. Rev. 2014, 78, 176-197. [CrossRef] [PubMed]

147. Bhatt, P.; Joshi, T.; Bhatt, K.; Zhang, W.; Huang, Y.; Chen, S. Binding interaction of glyphosate with glyphosate oxidoreductase and C-P lyase: Molecular docking and molecular dynamics simulation studies. J. Hazar. Mater. 2021, 409, 124927. [CrossRef] [PubMed]

148. Kishore, G.M.; Jacob, G.S. Degradation of glyphosate by Pseudomonas sp. PG2982 via a sarcosine intermediate. J. Biol. Chem. 1987, 262, 12164-12168. [CrossRef]

149. Pipke, R.; Amrhein, N.; Jacob, G.S.; Schaefer, J.; Kishore, G.M. Metabolism of glyphosate in an Arthrobacter sp. GLP-1. Eur. J. Biochem. 1987, 165, 267-273. [CrossRef] [PubMed]

150. Balthazor, T.M.; Hallas, L.E. Glyphosate-degrading microorganisms from industrial activated sludge. Appl. Environ. Microbiol. 1986, 51, 432-434. [CrossRef]

151. Sviridov, A.V.; Shushkova, T.V.; Zelenkova, N.F.; Vinokurova, N.G.; Morgunov, I.G.; Ermakova, I.T.; Leontievsky, A.A. Distribution of glyphosate and methylphosphonate catabolism systems in soil bacteria Ochrobactrum anthropi and Achromobacter sp. Appl. Microbiol. Biotechnol. 2012, 93, 787-796. [CrossRef]

152. Masotti, F.; Garavaglia, B.S.; Piazza, A.; Burdisso, P.; Altabe, S.; Gottig, N.; Ottado, J. Bacterial isolates from Argentine Pampas and their ability to degrade glyphosate. Sci. Total Environ. 2021, 774, 145761. [CrossRef] [PubMed]

153. Mousa, N.K.; Ali, A.J.; Hussein, M. Bacillus Megaterium Biodegradation Glyphosate; IntechOpen: Rijeka, Croatia, 2021 ; pp. 1-9. [CrossRef]

154. Elarabi, N.I.; Abdelhadi, A.A.; Ahmed, R.H.; Saleh, I.; Arif, I.A.; Osman, G.; Ahmed, D.S. Bacillus aryabhattai FACU: A promising bacterial strain capable of manipulate the glyphosate herbicide residues. Saudi J. Biol. Sci. 2020, 27, 2207-2214. [CrossRef] [PubMed]

155. Firdous, S.; Iqbal, S.; Anwar, S. Optimization and modeling of glyphosate biodegradation by a novel Comamonas odontotermitis P2 through response surface methodology. Pedosphere 2020, 30, 618-627. [CrossRef]

156. Góngora-Echeverría, V.R.; García-Escalante, R.; Rojas-Herrera, R.; Giácoman-Vallejos, G.; Ponce-Caballero, C. Pesticide bioremediation in liquid media using a microbial consortium and bacteria-pure strains isolated from a biomixture used in agricultural areas. Ecotox. Environ. Saf. 2020, 200, 110734. [CrossRef] [PubMed]

157. Acosta-Cortés, A.G.; Martinez-Ledezma, C.; López-Chuken, U.J.; Kaushik, G.; Nimesh, S.; Villarreal-Chiu, J.F. Polyphosphate recovery by a native Bacillus cereus strain as a direct effect of glyphosate uptake. ISME J. 2019, 13, 1497-1505. [CrossRef] [PubMed]

158. Pérez-Rodríguez, M.; Melo, C.; Jiménez, E.; Dussán, J. Glyphosate bioremediation through the sarcosine oxidase pathway mediated by Lysinibacillus sphaericus in soils cultivated with potatoes. Agriculture 2019, 9, 217. [CrossRef]

159. Singh, S.; Kumar, V.; Singh, J. Kinetic study of the biodegradation of glyphosate by indigenous soil bacterial isolates in presence of humic acid, Fe (III) and Cu (II) ions. J. Environ. Chem. Eng. 2019, 7, 103098. [CrossRef]

160. Ezaka, E.; Akintokun, A.K.; Akintokun, P.O.; Taiwo, L.B.; Uthman, A.C.O.; Oyedele, O.A.; Aluko, O.I. Glyphosate degradation by two plant growth promoting bacteria (PGPB) isolated from rhizosphere of maize. Microb. Resea. J. Inter. 2018, 26, 1-11. [CrossRef]

161. Chauhan, M.P.; Singh, N.K.; Chaudhary, A.K.; Shalini, R. Characterization of rhizobium isolates from Sesbania rhizosphere and their role in bioremediation of glyphosate and Monocrotophos. Int. J. Appl. Nat. Sci. 2017, 6, 11-22.

162. Ermakova, I.T.; Shushkova, T.V.; Sviridov, A.V.; Zelenkova, N.F.; Vinokurova, N.G.; Baskunov, B.P.; Leontievsky, A.A. Organophosphonates utilization by soil strains of Ochrobactrum anthropi and Achromobacter sp. Arch. Microb. 2017, 199, 665-675. [CrossRef] [PubMed]

163. Correa, L.O.; Bezerra, A.F.M.; Honorato, L.R.S.; Cortêz, A.C.A.; Souza, J.V.B.; Souza, E.S. Amazonian soil fungi are efficient degraders of glyphosate herbicide; novel isolates of Penicillium, Aspergillus, and Trichoderma. Braz. J. Biol. 2021, 83, e242830. [CrossRef] [PubMed]

164. Njoku, K.L.; Eludini, P.O.; Adesuyi, A.A.; Ude, E.O.; Oyelami, A.O. Physiological and molecular characterization of active fungi in pesticides contaminated soils for degradation of glyphosate. Res. Square 2020, 1-14. [CrossRef]

165. Swe, T.M.; Nandar, W.; Ei, H.H.; Win, N.N.; Swe, K.K.; kyaw Ko, T.; Win, T.T. Bio-removal efficiency of glyphosate by using indigenous laccase producing fungi. Int. J. Res. Appl. Sci. Biotechnol. 2020, 7, 249-256. [CrossRef]

166. Carranza, C.S.; Regnicoli, J.P.; Aluffi, M.E.; Benito, N.; Chiacchiera, S.M.; Barberis, C.L.; Magnoli, C.E. Glyphosate in vitro removal and tolerance by Aspergillus oryzae in soil microcosms. Int. J. Environ. Sci. Technol. 2019, 16, 7673-7682. [CrossRef]

167. Salman, J.M.; Abdul-Adel, E. Potential use of cyanophyta species Oscillatoria limnetica in bioremediation of organophosphorus herbicide glyphosate. Meso. Environ. J. 2015, 1, 15-26.

168. Carranza, C.S.; Barberis, C.L.; Chiacchiera, S.M.; Magnoli, C.E. Assessment of growth of Aspergillus spp. from agricultural soils in the presence of glyphosate. Rev. Argent. Microbiol. 2017, 49, 384-393. [CrossRef] [PubMed] 
169. Kulikova, N.A.; Zhelezova, A.D.; Filippova, O.I.; Plyushchenko, I.V.; Rodin, I.A. The Degradation of Glyphosate and Its Effect on the Microbial Community of Agro-Sod-Podzolic Soil under Short-Term Model Experiment Conditions. Mosc. Univ. Soil Sci.Bull. 2020, 75, 138-145. [CrossRef]

170. Mesnage, R.; Oestreicher, N.; Poirier, F.; Nicolas, V.; Boursier, C.; Vélot, C. Transcriptome profiling of the fungus Aspergillus nidulans exposed to a commercial glyphosate-based herbicide under conditions of apparent herbicide tolerance. Environ. Res. 2020, 182, 109116. [CrossRef]

171. Guo, J.; Song, X.; Zheng, C.; Sun, S.; Zhuang, B.; Tao, B. Transcriptome analysis and identification of candidate genes involved in glyphosate resistance in the fungus Fusarium verticillioides. J. Environ. Sci. Health. Part B 2021, 56, 658-669. [CrossRef] 